Studia Anglica Posnaniensia 52(2), 2017

doi: 10.1515/Stap-2017-0008

\title{
THE LOSS OF GRAMMATICAL GENDER AND CASE FEATURES BETWEEN OLD AND EARLY MIDDLE ENGLISH: ITS IMPACT ON SIMPLE DEMONSTRATIVES AND TOPIC SHIFT
}

\author{
RAFAE JURCZYK*
}

University of Opole

\begin{abstract}
In this paper we examine the relation between the loss of formal gender and Case features on simple demonstratives and the topic shifting property they manifest. The examination period spans between Old English and Early Middle English. While we argue that this loss has important discourse-pragmatic and derivational effects on demonstratives, we also employ the Strong Minimalist Hypothesis approach (Chomsky 2001) and feature valuation, as defined in Pesetsky \& Torrego (2007), to display how their syntactic computation and pragmatic properties have come about. To account for the above innovations yielding the Early Middle English pe ('the'), we first discuss the formal properties of the Old English demonstratives which distinguish number, gender, and Case features. This inflectional variety of forms allows the Old English demonstratives to be used independently and to show the anaphoric and discourse-linking properties of topics. Crucially, the same properties characterise also German and Dutch demonstratives that manifest Case and/or gender morphology overtly, which shows that the syntactic distribution of LIs and their morphological richness should be considered as intertwined. The above properties are then confronted with the determiner system in Early Middle English, whose forms undergo inflectional levelling producing the invariant pe/ðe form that loses its distributional independence and acquires the article status. The levelling process in question is argued to stimulate the shift of the $[+\mathrm{ref} / \mathrm{spec}]$ feature from the formal to the semantic pole. This suggests that the Early Middle English pe form no longer counts as an appropriate anaphor in topic shift contexts owing to its indeterminacy of Case, gender, and $\varphi$-features, which means that it cannot satisfy the Full Interpretation requirement at the interfaces.
\end{abstract}

Keywords: inflectional morphology; topic shift; the loss of formal gender and Case; OE/EME demonstratives.

English Philology, University of Opole, ul. Żeromskiego 1A/1, 48-304 Nysa, Poland, mortuus86@gmail.com. 


\section{Introductory remarks ${ }^{1}$}

The examination we provide attempts to show that the loss of morphological gender and Case by demonstratives between Old English (OE) and Early Middle English (EME) caused syntactic and pragmatic changes affecting derivation and word order. We discuss some reasons for the disappearance of the following uses of the OE demonstratives ${ }^{2}$ :

(1) a.

\begin{tabular}{l|l|l|l|l|l|l|l}
\hline Ic & geseah & wingeard $_{i .}$ & On & pam $_{i}$ & waeron & III & clystru \\
\hline I & saw & vineyard & in & that $_{\text {masc }}$ & were & three & vines \\
\hline
\end{tabular}
'I saw a vineyard. It had three vines/In it were three vines.' (Los 2012: 36, Gen
(Ker) 40.9-10)

b. (Ac gecuron him anne scop to cyninge of Atheniensem, and eft mid firde foran wip pa Messene. pa hi him nealcehtan, pa getweode hie hwceder hie wid him mohten.)

\begin{tabular}{|c|c|c|c|c|c|c|c|}
\hline $\mathrm{Se}$ & heora & cyning & ongan & ðа & singan & and & giddian \\
\hline $\mathrm{SE}$ & their & king & began & then & sing & and & recite \\
\hline
\end{tabular}

In (1a) the masculine pam ('that') refers back to the antecedent in the previous clause. In (1b) the masculine se ('that one') is an independent pronoun coreferring with the previous referent. We also examine the concomitant change in feature valuation between OE and EME - this being roughly as in (2a) and (2b), respectively. In (2a) the demonstrative raises to [Spec, DP] to value $\mathrm{D}^{0}$ 's [i $u$ val] [+ref] feature. In (2b) pe is inserted directly in $\mathrm{D}^{0}$ owing to the loss of formally-driven movement to $\mathrm{D}^{0}$, which implies syntax-semantic and morphological changes affecting the EME D-system.

1 The abbreviations used in the paper: DP - determiner phrase; D - demonstrative; PP prepositional phrase; CP - Complementiser Phrase; TP - Tense Phrase; TopP - Topic Phrase; FocP - Focus Phrase; $v \mathrm{P}$ - the complete argument structure, i.e., the verb with all its thematic roles; $\mathrm{X}^{0}$ - a head of some projection (e.g., $\mathrm{D}^{0}$ or Top ${ }^{0}$ ); SMT - Strong Minimalist Thesis; NS - narrow syntax; LF - Logical Form; LI - lexical item; nom - nominative; gen - genitive; dat - dative; acc - accusative; obl - oblique Case forms; N - noun; FI - (the principle of) Full Interpretation; $[ \pm \mathrm{Sg}]$ - singular/plural; $[i]$ - interpretable; $[u]$ - uninterpretable; [val] - valued; $[u \mathrm{val}]$ - unvalued.

2 Examples used in the article come from other authors' works, while some have been drawn from the YCOE corpus. 




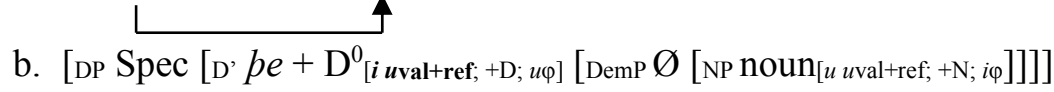

Let us now briefly discuss the notions/operations important for our analysis. Sections of the paper dealing with morphology are based on Pinker's (1994) approach to feature valuation. In a nutshell, the outcome of two morphologically different lexical items (e.g., A, B) yields a binary feature distinguishing the two forms. No feature comes up, if there is no morphological distinction (e.g., A, A). The above perspective will become important while discussing morphological contrasts in Case and gender from the formal and discourse-pragmatic perspective.

The viewpoint that OE and EME demonstratives, determiner phrases (DPs), or other constituents move to Topic Phrase (TopP) is based on Kiss (2002) and Beghelli \& Stowell (1994), who take this operation to be driven by Top $\mathrm{P}^{0}$ which has a $[u \mathrm{val}]$ [+referential] feature. This is an important point, because Case and gender morphology, as defined here, lexicalise the category of definiteness. If we link the above with the proposal that inflectional morphology plays a role in narrow syntax (NS), it then becomes possible to conflate the loss of morphology between $\mathrm{OE}$ and EME with syntactic and pragmatic changes in the D-system.

Finally, we adopt the feature valuation perspective, as defined in Pesetsky \& Torrego (2007). The Agree relation applies regardless of the feature's interpretability and "unifies two feature OCCURRENCES into two INSTANCES of one shared formal object" (Danon 2011: 307, capitals original). The approach does not require the Goal's feature to be [val] - the Agree relation between two [ $u \mathrm{val}]$ features is licit, if the next Agree relation values one of them, thus valuing all other instances of this feature:

(3) $\left[\mathrm{A}_{[\mathrm{valF}]} \ldots\left[\mathrm{B}_{[u \mathrm{valF}]} \ldots\left[\mathrm{C}_{[u \mathrm{valF}]}\right]\right]\right.$

In (3), $\mathrm{B}$ and $\mathrm{C}$ enter derivation with two instances of the same [ $u \mathrm{val}]$ feature. Prior to the merger of $\mathrm{A}, \mathrm{B}$ and $\mathrm{C}$ agree for the $[u \mathrm{val}]$ feature. Once $\mathrm{A}$ is merged, it agrees with $\mathrm{B}$ and values its [ $u \mathrm{val}$ feature, which makes C's [uval] feature valued too, even though A does not agree with $\mathrm{C}$.

The paper is organised as follows. In section 2 we provide a brief overview of the scholarly works that tackle the issue of syntax-semantic properties of demonstratives between OE and EME. We focus mostly on accounts from a clause-oriented perspective. The purpose of the overview is to highlight the main issues on the topic that seem still to be unresolved, and which are crucial for the fuller understanding of the changes in question. Section 3 focuses on 
several issues: the syntactic heterogeneity of the $\mathrm{OE}$ demonstratives, morphological contrasts they manifest, and the importance of inflectional morphology in NS. We also discuss demonstratives' feature valuation from the phrasal and clausal perspective and show that similar syntax-semantic properties of German, Dutch, and Old English demonstratives come from the fact that they all manifest Case and gender morphology. In section 4 we show how the demise of Case and gender affects the formal and pragmatic properties of the EME demonstratives, as well as their distribution in the clause and sentence. We also provide remarks on the emergence of the morphologically invariant $p e$ that marks the birth of the definite article in English. Finally, we argue that the approach used in this paper can account for the distributional properties of the $\mathrm{OE}$ demonstratives and pronominals in a more principled way than the one offered by van Gelderen (2011a, 2011b), in which morphology is ignored. Section 5 concludes the discussion.

\section{Literature overview}

The scholarly works that discuss the topic of the OE demonstrative system and its properties are numerous and follow both narrow, DP-oriented perspectives and broader, sentence-oriented ones. Some noteworthy examples of the former include Allen (1995, 2006, 2012) and Wood (2007), who examine the properties of the $\mathrm{OE}$ demonstratives in co-occurrence with adjectives or quantifiers in the DP. Examples of the latter include Osawa (2007), Watanabe (2009), van Gelderen (2011a, 2011b), Crisma (2011), Los (2012), and Breban (2012). These scholars discuss demonstratives with respect to a variety of sentence-related phenomena such as relativisation and discourse-linking. Interestingly, most of such works follow either of the two viewpoints. In the first, the OE D-system and changes affecting it are examined from a purely formal perspective, whereby all syntax-semantic differences are accounted for by structural constraints, syntactic operations, or types of features. In the second, there is a syntactic framework which serves the purpose of examining syntax-semantic changes. In such a perspective, remarks on morphology (a system unrelated to syntax) are meant to represent the post-syntactic process of lexicalising the operations taking place in NS.

For example, in Los (2012), it is noted that verb-second allows the first position in the $\mathrm{OE}$ clause to be occupied by topicalised lexical items like adverbs or demonstratives for the purpose of discourse-referencing. As regards demonstratives, Los draws attention to the loss of gender as crucial to the demise of discourse reference manifested by sentence-initial topics. Interestingly, Los (2012) neither provides a definition of what morphology is, nor does she explain how it affects so deeply the semantics and syntax of 
English in a diachronic perspective. This leaves the changes taking place in a vacuum, i.e., with no reference to formal rules and structural constraints driving the computation of lexical material. As it turns out, the examination along purely formal and structural constraints yields the same effect. In Watanabe (2009), the relation between syntactic changes in the clause and the ones in the D-system is exemplified by relativisation, whereby demonstrative pronouns behave as Modern English (ModE) which or who. The OE demonstrative pronouns move to $[\mathrm{Spec}, \mathrm{CP}]$ from where they agree with a higher probe in the matrix clause - the agreement relation valuing the $[u \mathrm{val}]$ definiteness feature on the relative pronoun. Making definiteness a formal feature allows Watanabe to account for the loss of demonstrative relative pronouns in EME by claiming that the agreement relation is lost, and/or that the definiteness feature has changed from formal to semantic. But while positing that the formal definiteness feature provides the answer to why the EME demonstratives lack relative properties, it does not answer the question how such a change takes place. A simple feature shift cannot be the sole reason for the disappearance of the OE-type demonstrative relative pronouns. If it were, the EME $p e$ or the ModE the would compete for that function and position with who or which.

\section{On the properties of $\mathrm{OE}$ demonstratives ${ }^{3}$}

\subsection{OE demonstratives as specifiers and heads}

The syntax-semantic heterogeneity of the OE demonstratives is manifested in several ways, including, for example, the structural positions they occupy, and the ways in which they induce feature valuation. While some of these properties have already been subject to numerous examinations, it is impossible to disregard them here, because, as will be argued, syntax and inflectional morphology are inextricably interconnected with NS derivation. Below, it can be seen that the $\mathrm{OE}$ demonstratives are specifiers (Brugè 2002; Bartnik 2007) in [Spec, DP] showing similar inflectional endings to OE adjectives or quantifiers:

(4) a.

\begin{tabular}{l|l|l}
\hline done & ælmihtigan & God \\
\hline the & almighty & God $_{\mathrm{ACC}}$ \\
\hline \multicolumn{2}{l}{ 'the almighty God' $(\mathrm{CH}, 246)$} &
\end{tabular}

We take the DP to dominate the NP in OE and (E)ME without motivating this. Some factors contributing to this assumption are the co-occurrence of demonstratives/determiners and possessives, N-to-D-movement and similarities in clausal/nominal arrangement of lexical material. See Alexiadou, Haegeman \& Stavrou (2007) for a detailed analysis. 
b.

\begin{tabular}{l|l}
\hline God & ælmihtigne \\
\hline God & almightyACC \\
\hline 'God almighty' (Bartnik 2007: 79) & \\
\hline
\end{tabular}

c.

\begin{tabular}{l|l|l|l}
\hline on & sumne & blindne & seað \\
\hline into & some & blind & pit \\
\hline
\end{tabular}

'into some blind pit' (Bartnik 2007: 78)

Moreover, examples (4a) and (4b) display two ways of inducing spec-head agreement with relevant heads. In (4a) there is a specifier-head agreement between the determiner in [Spec, DP] and the $\mathrm{D}^{0}$ for the $[+$ ref $]$ feature. This agreement type derives the weak adjectival ending - an because the adjective and the $\mathrm{D}^{0}$ do not enter into agreement. In examples like (4b) it is usually assumed that the noun moves to $\mathrm{D}^{0}$ (quite possibly to value $\mathrm{D}^{0}$ s $u \varphi$-features), while the adjective agrees with $\mathrm{D}^{0}$ for the $\left[+\right.$ ref] feature ${ }^{4}$. The syntactic heterogeneity of the OE demonstratives can also be seen in the two constituent word orders, i.e., $[\mathrm{D}>$ possessive $>\mathrm{N}]$ and [possessive $>$ $\mathrm{D}>$ adjective] represented in (5). In the former word order, the demonstrative is commonly taken to be in [Spec, DP], but in $\mathrm{D}^{0}$ in the latter.

(5) [demonstr. $>$ possessive $>$ noun] / [possessive $>$ demonstr. $>$ adjective] word orders

\begin{tabular}{l|l|l|l|l|l|l|l}
\hline pysne & eowerne & cyning & $/$ & his & bam & leofan & pegne \\
\hline this & your & king & $/$ & his & the & dear & thane \\
\hline 'this king of yours' (Allen 2006: & $/$ & $\begin{array}{l}\text { 'his dear thane' (Allen 2006: 150, } \\
\text { 149, Vercelli I.135) }\end{array}$ & & $\begin{array}{l}\text { Vercelli I.231) } \\
\text { ? }\end{array}$
\end{tabular}

In the [demonstrative $>$ possessive] word order the demonstrative and the possessive are in specifier positions - in DP and in Possessive Phrase, respectively. In the [possessive $>$ demonstrative $>$ adjective] constituent word order, the movement of the possessive above the demonstrative is possible because the demonstrative and the adjective are located under DP, which makes [Spec, DP] empty ${ }^{5}$.

$4 \quad$ For Bartnik (2007), adjectives in examples like (4b) are in [Spec] of an Adjectival Phrase below the DP and the Possessive Phrase (cf. Fischer, van Kemenade, Koopman \& van der Wurff 2000). Bartnik (2007) takes the [+ref] feature to trigger N-to-D-movement and the adjective to check the accusative Case feature in the functional projection. For Watanabe (2009), weak adjectival agreement with $\mathrm{D}^{0}$ in examples like (4b) is triggered by the [def] feature which is $[i]$ on $\mathrm{D}^{0}$ and $[u]$ on the weak adjective. It seems that [def] on the strong adjective is $[u]$ too, as he claims it to be so even on Case-/gender-marked forms like ðone.

5 In the possessive $>$ demonstrative $>$ adjective sequence the adjective is argued to project its 
As regards the pronominal properties of the demonstratives, they are visible in (6) and (7).

(6)

\begin{tabular}{l|l|l|l|l|l|l}
\hline Eneas & wæs & Veneres & sunu; & se & oferswiðe & Turnum \\
\hline Eneas & was & Venus' & son & D MASC.SG & conquered & Turnum \\
\hline
\end{tabular}

'ÆEneas was Venus' son; he is/was the one that conquered Turnum' (Los 2012: 39, ÆGram 98.22)

(7)

\begin{tabular}{l|l|l|l|l|l|l|l}
\hline Ic & geseah & wingeard $_{i .}$ & On & pam $_{i}$ & waeron & III & clystru \\
\hline I & saw & vineyard & in & that $_{\text {masc }}$ & were & three & vines \\
\hline
\end{tabular}
'I saw a vineyard. It had three vines/In it were three vines.' (Los 2012: 36, Gen
(Ker) 40.9-10)

In (6) and (7) the demonstratives are used anaphorically, i.e., they refer back to their antecedents and are assumed to occupy the $\mathrm{D}^{0}$ position.

\subsection{OE demonstratives: Morphological contrasts in Case and gender}

In Table (1) we show Case and gender forms manifested in the OE D-system.

Table 1. Inflectional endings in simple demonstratives in OE (Millar 2000: 21)

\begin{tabular}{|c|c|c|c|c|}
\hline \multicolumn{4}{|c|}{ Singular } & Plural \\
\hline Case & Masculine & Feminine & Neuter & all genders \\
\hline Nominative & se & sēo & pæt & pā \\
\hline Genitive & pæs & pǣre & pæs & pāra \\
\hline Dative & pǣm & pǣre & pǣm & pǣm \\
\hline Accusative & pone & $\mathrm{p} \overline{\mathrm{a}}$ & pæt & $\mathrm{p} \overline{\mathrm{a}}$ \\
\hline
\end{tabular}

There is a full gender distinction in the nominative and accusative, which allows us to postulate the three-value feature that disambiguates between three gender forms - masculine, feminine, and neuter. In genitive and dative contexts, there is one common gender form subsuming masculine and neuter, which yields the binary-value feature: feminine and masculine/neuter. The plural paradigm is unmarked for gender, and hence, it is rendered as [agender]. In the nominative

own extended projection, i.e., DP with the demonstrative in $\mathrm{D}^{0}$. Allen (2006) and Wood (2007) conflate this discrepancy with the fact that this sequence represents the grammaticalisation of the demonstrative which is here the pure definiteness marker (Wood 2007: 357). 
and accusative contexts, Case and gender are fully disambiguated, which yields a four-value Case feature and a three-value gender feature. As regards feminine demonstratives, their forms allow us to postulate a three-value feature. In the plural, all demonstratives show full distinction into Case, which, again, means that we can postulate a four-value Case feature. We sum up the above contrasts in $(8 a-b)$.

(8)a. the richest opposition: [nom; gen; dat; acc], [masc; fem; neut]

b. the poorest opposition: [nom; gen/dat; acc], [agender]

As regards Case, it marks the grammatical relation with the remaining constituents which is constrained by verbal agreement that the DP triggers or not and by the structural position it occupies in the clause (Blake 1994: 1). As will be seen, the more inflectional morphology a lexical item (LI, henceforth) shows the more preferable it seems to be by the principle of Full Interpretation $(\mathrm{FI})^{6}$. The same is going to be assumed with respect to the category of gender despite its more elusive role in syntax ${ }^{7}$. For example, Josefsson (2013: 11-18) notes that formal gender encodes (in)definiteness in Swedish et hus ('a house') and huset ('the house') where (-)et is neuter. In contrast, Greek gendered articles do not seem to mark (in)definiteness. While the gendered article fixes gender on the noun jatros ('doctor') which may be masculine or feminine, gendered adjectives in article-less constructions do not make the noun's reading definite, but predicative (Ralli 2003). In other words, formal gender is dummy having no meaning per se (cf. Picallo 2008; Carstens 2010; Josefsson 2013), which prompts various scholars to see it as $[u]$ because the membership in a grammatical gender is arbitrary. While this is uncontroversial, there is a clear correlation between gender and Case morphology, and the availability of topic shift (cf. Los 2012; Breban 2012). If this correlation indeed holds, then it does not seem coincidental that the EME pe cannot be used independently and show syntax-semantic properties characteristic of demonstratives in OE, German, or Dutch.

6 See Ura (2000) for similar claims about Case-marked NPs/DPs. In Chomsky (1995), PF (providing an audible representation of an utterance) and LF (generating an interpretable representation of an utterance) constitute two interfaces to two further components in the human mind. A given portion of NS derivation satisfies FI by being interpretable at these two interfaces.

7 There is cross-linguistic evidence for Number Phrase (e.g., Ritter 1991 on Hebrew; Valois 1991 on Romance languages). Similarly, the phenomenon of Case projections is often dubbed as KP, i.e., Kase Phrase (e.g., Toman 1994; Hale \& Bittner 1996). The efforts to account for the syntactic reflex of gender (e.g., Ritter 1993; Di Domenico 1997) remain largely inconclusive. 
It thus seems justified to consider the possibility that inflectional morphology is a fully-fledged component of syntax. We offer some arguments in favour of this assumption in the next section.

3.3. Inflectional morphology in syntax: A view from the SMT-based perspective

According to the Strong Minimalist Thesis (Chomsky 2001: 1), language is an optimal system for turning material from NS computation into PF- and LFinterpretable outputs, which implies that PF and LF forms must correspond to each other. While this is uncontroversial, it often seems to be disregarded, as in Embick \& Noyer (2001: 555), who claim that "not all structures and strings are the result of operations that occur exclusively in the syntactic component of the grammar". Inflectional morphology is thus added to NS derivation by means of PF-autonomous rules within the Distributed Morphology approach (cf. Halle \& Marantz 1993).

As already noted, works following the tenets of the Minimalist Programme tend to keep morphology aside from NS too. In van Gelderen (2011a, 2014), for example, the demise of the deictic and anaphoric properties of the $\mathrm{OE}$ demonstratives is handled without resorting to inflectional morphology. This seems to question the optimal design property of language, i.e., the fact that it works on the syntactic template(s) to satisfy the requirements of languageexternal systems (Moro 2008; Tajsner 2012) that justify the presence of PF and LF as the only representational levels (Chomsky 1995; Willim 2012).

Let us consider some examples from Icelandic and Polish where inflectional morphology is disregarded as a component of NS derivation. Sigurðsson (1996) for example, examines verb-object agreement in Icelandic characteristic of verbs like leiðast ('to bore'), or lika ('to like'). The agreement (in bold) is most common between the subject and the verb, yet sometimes it seems to hold between the verb and the object.

(9) a.

\begin{tabular}{l|l}
\hline Strákarnir & leiddust \\
\hline the boySpL & walked hand in hand $3 \mathrm{PL}$ \\
\hline
\end{tabular}

b.

\begin{tabular}{l|l|l}
\hline Henni & leiddust & strákarnir \\
\hline herDAT & bored 3 PL & the boys 3 PL.NOM \\
\hline \multicolumn{2}{l}{ 'She found the boys boring.' }
\end{tabular}


In (9a) strákarnir ('the boysnom') is the subject that agrees with the verb. Sigurðsson, however, reanalyses nominative as inherent rather than structural, in order to account for (9b) with a 'nominative-non-subject' strákarnir ('the boys') and labels this phenomenon as 'verb-object agreement'. In a similar way, Barðdal (2001) assumes that the two word orders depend on categorisation frames - whichever order is chosen, the nominative or dative DP can be realised in the subject or in the object position. Let us note, however, that depending on the choice, the interpretation becomes slightly different (Jónsson 2003: 140).

(10) a.

\begin{tabular}{l|l|l}
\hline Ég & parf & peninga \\
\hline I 1 SG.NOM $^{\prime}$ & need 1SG.PAST & moneyACC \\
\hline
\end{tabular}

b.

\begin{tabular}{l|l|l}
\hline Mig & vantar & peninga \\
\hline I $_{\text {1SG.ACC }}$ & needs3SG.PRES & moneyACC \\
\hline \multicolumn{2}{l}{ 'I need money (right now).' } \\
\hline
\end{tabular}

With respect to the above data, let us now consider Polish examples. Citko (2014: 35, fn.9) takes a similar viewpoint as Sigurðsson and Barðdal while analysing examples (11a-b). In a nutshell, in (11b) the dative DP Marii ('MariaDAT') is dubbed as subject, while the nominative DP kwiaty ('flowersNom') is dubbed as object in a similar way as the nominative strákarnir ('the boys') in Icelandic. Interestingly, the nominative DPs are dubbed objects because the subject positions are occupied by dative/quirky subjects ${ }^{8}$.

(11) a.

\begin{tabular}{l|l|l|l}
\hline Maria & nie & lubi & kwiatów/*kwiaty \\
\hline Marianom & not & please & flowers ${ }_{\mathrm{GEN}} / *_{\mathrm{ACC}}$ \\
\hline \multicolumn{3}{l}{} \\
'Maria does not like flowers.'
\end{tabular}

b.

\begin{tabular}{l|l|l|l|l}
\hline Marii & nie & podobają & się & kwiaty $/ *_{\text {kwiatów }}$ \\
\hline MariaDAT & not & please & refl.cl. & flowers ${ }^{2} /{ }^{\text {GEN }}$ \\
\hline
\end{tabular}

8 Example (11a) is provided by Citko (2014) to show that the nominative Case on the object in (11b) results from Agree with $\mathrm{T}^{0}$ rather than $v^{0}$. This is because the Case remains nominative under negation, unlike the accusative which shows Genitive of Negation. See Citko (2014), and the references cited below for discussion. See Malak (2008) and Jurczyk (2015) for critical remarks on the quirky subjects notion. 
In other words, Citko, Sigurðsson, and Barðdal argue that the initial DP can receive the interpretation of the subject regardless of the Case form it has. Oblique DPs are termed subjects because they pass tests for subjecthood which include, mainly, syntactic phenomena (e.g., raising and conjunction reduction see Boeckx 2000 for a comprehensive survey). Such subjecthood tests are not uniformly passed by Icelandic and Polish oblique DPs (those in Polish disallow, for example, conjunction reduction - cf. Bondaruk \& Szymanek 2007). Interestingly, when we consider semantic issues, the interpretation differs in the same way in the two languages depending on whether the initial DP is nominative or oblique. In (10a)-(11a), with nominative DPs, the interpretations are that I need money (Icelandic) and that Maria does not like flowers (Polish). In (10b)-(11b) the interpretations are that I lack/need money right now (Icelandic) and that Maria is not pleased with flowers (Polish). We could say that nominative DPs indicate that subjects perform the action or express some mental state they are in, using their own energy (Jónsson 2003: 135) where the energy should be understood in its physical and mental aspect. Oblique DPs seem to receive sensations, feelings, or physical states passively. Such interpretational differences should not occur, if inflectional morphology made no contribution to syntax and interpretation. Moreover, the viewpoint advocated by Citko, Sigurðsson, or Barðdal runs counter to what Chomsky (1995) claims in that "the lexicon specifies elements that CS [computational system - the present author] selects and integrates to form linguistic expressions - (PF and $L F)$ pairings [italics ours - the present author]...” (Chomsky 1995: 6).

Let us now discuss the formal status of gender and Case in NS. It is commonly held that $\varphi$-features on determiners/demonstratives are $[u]$ and do not receive interpretation at the interfaces ${ }^{9}$. They are, nevertheless, $[i]$ on nouns or pronouns like he or her (Radford 2004; Pesetsky \& Torrego 2007) because they represent the nominal category. At this point, it seems necessary to specify what 'interpretable' means for NS. According to Adger \& Svenonius (2009), interpretable formal features "are those, that are used, in the final representation, to connect with the semantic systems (or the phonological ones)" (Adger \& Svenonius 2009: 18). Chomsky (1995) notes that "some features remain visible at LF... for example $\varphi$-features of nouns, which are interpretable" (Chomsky 1995: 279). Adger (2003) says that "syntactic features may also be accessed by the rules of semantic interpretation. Those features which have this effect are called interpretable features" (Adger 2003: 53) and he adds that " $\varphi$-features appear to be interpretable, and are motivated by both semantic and morphological facts" (Adger 2003: 45). If we give credence to the above characteristics of feature interpretability, we could propose that what it means is

$9 \quad$ See Harley \& Noyer (1999), Embick \& Noyer (2001), and Kuno (2011). 
PF- and/or LF-visibility, which accounts for the interpretability of English pronouns - they are visible at the two interfaces and contribute to interpretation (Kibrik 2011).

(12) a.

\begin{tabular}{l|l|l|l|l|l|l|l|l|l|l}
\hline I & talked & to & Joe $_{\text {masc }}$ & and & Sally $_{\text {fem. }}$ & $H e_{\text {masc }}$ & was & agreeable. & $S$ She $e_{\text {fem }}$ & wasn't \\
\hline
\end{tabular}

b.

\begin{tabular}{|c|c|c|c|c|c|c|c|}
\hline Ic & geseah & wingeard $_{i .}$ & On & pami $_{i}$ & waeron & III & clystru \\
\hline I & saw & vineyard & in & that ${ }_{\text {masc }}$ & were & three & vines \\
\hline
\end{tabular}

The italicised forms in (12a-b) provide unambiguous anaphoric reference - the masculine he in (12a) co-refers with Joe, and the feminine she co-refers with Sally. The OE masculine pam ('that') in (12b) yields the same effect, as it corefers with the masculine wingeard ('vineyard'). Notably, specific reference is made available by formal Case and gender - while the former manifests the grammatical relation a DP has with other constituents, the latter allows for specific reference to hold. In effect, Case and gender seem to be $[i]$ by being visible at $\mathrm{PF}$ and LF, and connecting with semantic and phonological systems. If so, they play a role in NS in a similar way as, say, the negation feature which triggers neg-inversion and makes TP interpreted as denial (Adger \& Svenonius 2009). Assuming the reasoning of Adger \& Svenonius (2009), gender and Case features also play a role in syntax because gendered and Cased DPs can be topicalised and yield discourse-reference semantically. In other words, the perspective on the Case feature, as followed here, complies with the notion of Visibility Condition (Chomsky 1981, 1986), i.e., that only Case-assigned constituents are LF-visible and marked for $\theta$-role assignment, thereby possessing the status of an argument.

Importantly, as regards the status of the gender feature on the $\mathrm{OE}$ demonstratives, we assume that it is not only pronominal demonstratives, but also their phrasal instances that possess the [i] gender feature. In traditional approaches towards feature interpretability it is claimed that gender agreement results from the nominal property, i.e., the fact that nouns enter Lexicon specified as masculine, or feminine (e.g., Pesetsky \& Torrego 2007). Thus, the gender feature on demonstratives or adjectives is [uval], being valued by a nominal counterpart under agreement. But the fact that the gender feature on demonstratives or adjectives is [ $u \mathrm{val}]$ does not exclude the possibility that it is still [i] (cf. van Gelderen 2011a on OE, and Bošković 2011 on Serbo-Croatian), especially if we put aside, for a moment, syntactic computation where all formal 
operations take place. What seems to matter, in the end, is FI that a given LI receives. If we consider the $\mathrm{OE}$...Ic eom ealne pone hefon ymbhweorfende. ('... I attend to all heaven.') (coboeth,Bo:7.18.5.289, Bartnik 2011: 87), it is the demonstrative that contributes to interpretation - not only of the demonstrative itself, but also of the nominal complement which manifests neither gender nor Case $^{10}$. Owing to this property, the $\mathrm{OE}$ demonstratives also act as discourse devices, apart from making nominal complements referential. However, despite carrying the $[i]$ gender feature, phrasal demonstratives in $\mathrm{OE}$ will be argued to enter derivation as $[u \mathrm{val}]$. This stems from the fact that it is only after agreeing with the noun that the gender feature on the se demonstrative is valued, which is manifested by the relevant form (e.g., pone or pare).

Still, the viewpoint on morphology as sketched above, does not mean that formal gender and Case have meaning per se (cf. Josefsson 2013: 5, 11), but rather that they make visible the category of definiteness. As regards the Case feature, an important issue needs to be mentioned here. Unlike Bartnik (2011) or Neeleman \& Weerman (2001), we do not conflate it with any syntactic projection, but take it to reflect the structural position a DP has with other constituents in the clause. With respect to the above remarks, but also in accordance with the Visibility Condition, we represent the nominative Case feature as $[u$ uval]. Oblique Case forms will be $[i \mathrm{val}]$ because they carry gender and Case morphology and are, therefore LF- and PF-visible. The accusative Case will be treated as $[i u \mathrm{val}]$ because it is an instance of a structural Case in a similar way the nominative Case is. Crucially, morphological variation on $[+\mathrm{Sg}]$ demonstratives comprises gender and Case, i.e., it functions as a portmanteau suffix, making it hard to separate the two. This is an important observation because it indicates that topic shift becomes unavailable as soon as inflectional levelling becomes completed, yielding the invariable $p e$ form.

In the next section we examine the influence the Case and gender morphology has on NS derivation from the formal perspective.

10 While the issue of marking gender and Case features is simplified here (in ...begra ðara Jinena '...the two maids', (cootest,Gen:33.1.1348, Bartnik 2011: 72) both the demonstrative and the noun manifest gender and Case), the declensional paradigm of the OE D-system features much more distinctive forms than the nominal one which is characterised by a considerable level of syncretism (cf. Hogg \& Fulk 2011). Thus, nominal $\varphi$-features marking in $\mathrm{OE}$ seems to be the role of the D category rather than the category of nouns. 


\subsection{Feature valuation in $\mathrm{OE}$}

\subsubsection{Feature valuation within $\mathrm{DP}^{11}$}

Let us first consider feature valuation in the OE DP between the demonstrative and the noun (boldfaced features on these two categories agree with features on $\left.\mathrm{D}^{0}\right)$.



Unlike other scholars (e.g., Carstens 1993; Baker 2008; van Gelderen 2011a, $2011 \mathrm{~b})$, we take the person feature on the demonstrative to be $[u]$ and $[u \mathrm{val}]$ because it plays a minor role in referencing. We annotate the fact that the $\mathrm{OE}$ demonstratives possess $[i]$ Case and gender features, and a $[u]$ person feature as $i / u \varphi$. As for nouns, their $\varphi$-features are all [i], which will be annotated as $i \varphi$. Finally, we follow a common assumption that $\mathrm{D}^{0}$ probes the noun for $i \varphi-$ features, and that Case and gender features are shared between the noun and the demonstrative in that "it is both the feature type (person, number, Case etc) and the value that is shared" (Danon 2011: 307).

In (13) the demonstrative and the NP merge, and the former probes for the noun's $i \varphi$-features. This step values the demonstrative's $u$ person feature and hence the demonstrative and the noun now share all the $\varphi$-features that are valued. Next, $\mathrm{D}^{0}$ is merged and probes for $[i]$ features on the demonstrative and the noun, i.e., $[i+\mathrm{ref}]$ and $i \varphi$, respectively. At this step, there are three instances of shared $\varphi$ - and $[+$ ref] features that are valued. Importantly, DP now has a complete set of [val] $\varphi$-features shared between $\mathrm{D}^{0}$, demonstrative and noun, which means that when $\mathrm{T}_{[+\mathrm{T}, u \varphi, u \mathrm{D}]}$ is merged, it probes for the demonstrative which shares all the relevant [val] features (it is a $\varphi$-complete formal object). The consecutive derivational steps apply, for example, to (14a) which represents the (S)ubject (V)erb (O)bject order:

11 By using the [+ref] rather than [+def] feature, we follow Longobardi (1994), who claims that it is determiner's [+ref] property that turns the NP into an argument. Due to being formal, we also assume this feature to syntactically encode the semantic/pragmatic notion of definiteness, though it is only one of the possibilities (cf. Lyons 1999, where semantic definiteness is syntactically encoded by the formal [+def] feature). In fact, definiteness seems to subsume referentiality, as definite DPs require specific reference (e.g., Farkas \& von Heusinger 2003). 
(14) a

\begin{tabular}{l|l|l|l|l|l|l|l|l}
\hline Se & & messepreost & leofode & be & hlafe & and & be & wætere \\
\hline the NOM & & mass-priest & lived & on & breadDAT & and & on & water DAT \\
\hline \multicolumn{7}{c}{} \\
\hline
\end{tabular}

Let us now consider the distribution and feature valuation of the demonstrative pronoun within DP.

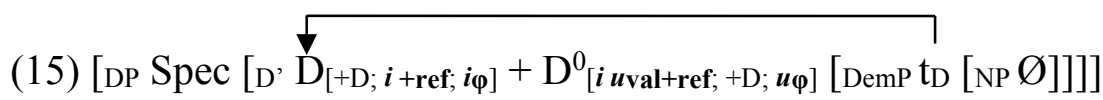

The demonstrative pronoun is base-generated lower than $\mathrm{D}^{0}-$ it moves there in a similar way the demonstrative does ${ }^{12}$. The lower position (Demonstrative Phrase) is assumed here because the $\mathrm{OE}$ demonstrative is not yet grammaticalised, i.e., it is not a category conflated solely with referentiality. The pronominal demonstrative values $[i u \mathrm{val}+\mathrm{ref}]$ and $\varphi$-features of $\mathrm{D}^{0}-$ the formal requirement to trigger Agree between the probe $\left(\mathrm{D}^{0}\right)$ and the goal (D). The valuation process in (15) applies, for example, to (16a-b).

(16) a.

\begin{tabular}{|c|c|c|c|c|c|}
\hline $\mathrm{Se}$ & heora & cyning & ongan & да & singan... \\
\hline the & their & king & began & then & sing \\
\hline
\end{tabular}

b.

\begin{tabular}{l|l|l|l|l|l|l}
\hline Eneas & wæs & Veneres & sunu; & se & oferswiðe & Turnum $^{13}$ \\
\hline Eneas & was & Venus' & son & DEM MASC.SG & conquered & Turnum \\
\hline \\
'Fneas was Venus' son; he is/was the one that conquered Turnum’ (Los 2012: \\
39, ÆGGram 98.22)
\end{tabular}

In (16a) se is probably in an apposition - being followed by a determiner-less $\mathrm{NP}$ heora cyning. We assume that the slot occupied by se is $\mathrm{D}^{0}$ where it is directly merged. This stems from the fact that a null $\mathrm{D}^{0}$ carries an $[i u \mathrm{val}+\mathrm{ref}]$

12 In this case we follow Giusti (2001) and Brugè (2002), but unlike them, we take the structural heterogeneity of demonstratives to be reflected also in the final landing site, i.e., [Spec, DP] vs. $\left[\mathrm{D}^{0}\right]$.

13 This is the option Breban (2012) hints on (cf. also Allen 2006 and Wood 2007). Crucially, se is not used here as a relative pronoun 'who'. The excerpt in (14b) is from Ælfric's Latin Grammar which is an OE translation of a Latin text in which the Latin counterpart is the demonstrative is ('that one'). 
feature and $u \varphi$-features which need to be valued. In (16b), the initial DP contains the pronominal se in $\left[\mathrm{D}^{0}\right]$, an anaphor which continues reference to the previously established topic Eneas. The DP then moves to [Spec, TP] to value the features of $\mathrm{T}^{0}$.

\subsubsection{Feature valuation in the clause}

OE has a relatively free constituent word order compared to ModE. Crucially, beside canonical SVO word orders (14a), it features, for example, V2 sequences $(17 \mathrm{c})$ in a similar way as other Germanic languages (17a-b):

(17) a. (Faroese)

\begin{tabular}{l|l|l|l|l}
\hline$[\dot{I}$ & ovurmorgin $]$ & hevur & Karin & føðingardag \\
\hline on & the day after tomorrow & king & Karin & birthday \\
\hline
\end{tabular}

'The day after tomorrow, Karin has her birthday.'

b. (German)

\begin{tabular}{l|l|l|l|l|l}
\hline$[$ Das & Buch $]$ & habe & Ich & schon & gelesen \\
\hline The & book & have & I & already & read \\
\hline \multicolumn{7}{c}{ 'That book, I've already read.' } \\
\hline
\end{tabular}

c. (Old English)

\begin{tabular}{l|l|l|l|l|l|l}
\hline$[$ On & his & dagum $]$ & sende & Gregorius & us & fulluht \\
\hline on & his & days & sent & Gregory & us & baptism \\
\hline
\end{tabular}

'In his time, Gregory sent us Christianity.'

In V2 environments the verb is in the second position following sentence-initial topicalised non-subjects. In (17a) and (17c) it follows prepositional phrases, and in (17b) it follows the DP fronted to [Spec, CP]. For the sake of examination, we follow here Biberauer \& Roberts's (2010) proposal that CP shares its $\varphi$ features and the $\mathrm{T}$-feature with $\mathrm{T}^{14}$. Assuming that $\mathrm{C}^{0}$ 's feature matrix is $[u \varphi$, $u \mathrm{~T}]$, the derivation of SVO and V2 contexts will differ depending on the feature distribution option that $\mathrm{C}^{0}$ will employ ${ }^{15}$. Let us focus on the former first, in

14 Chomsky $(2001,2004,2008)$ takes phase heads $\mathrm{C}^{0}$ and $v^{0}$ to trigger derivation by distributing $\varphi$ - and/or T-features to lower non-phase heads $\mathrm{T}^{0}$ and $\mathrm{V}^{0}$. Because $v \mathrm{P}$ plays no role in further discussion we disregard it here.

15 We differentiate between SVO and V2 because the latter predominantly raises a non-subject XP to the sentence-initial position followed by the finite verb in the second position. This naturally relates to another reason for such distinction, namely, the fact that topic shift, characteristic of oblique DPs, involves topical non-subjects rather than subjects. Despite the above, SVO word orders are often taken as instances of V2, i.e., IP-V2 sentences with the 
which the $u \mathrm{~T}$-feature and $u \varphi$-features are handed down to $\mathrm{T}^{0}$ that probes for $i \varphi$ features on the goal. As regards the T-feature, we follow here Biberauer \& Roberts (2010) who propose that it is $[u]$, but present on the $\mathrm{V}^{0}$ because nonfinite verbs cannot express tense relations. In the same way, the V-feature is $[u]$, but present on $\mathrm{T}^{0}$ because Tense is realised on the verb. As a result, we get $\mathrm{T}_{[u \mathrm{~V}]}^{0}$ and $\mathrm{V}_{[u \mathrm{~T}]}^{0}$ triggering $\mathrm{V}$-to- $\mathrm{T}$ movement that values the two features. Bearing these remarks in mind, let us consider the partial derivation in (18).



b. [vp se messepreost $\left[\mathrm{v}^{\prime}[\mathrm{v} \mathrm{v}[\mathrm{vp}[\mathrm{v},[\mathrm{v}\right.$ leofode [pp be hlafe and be wætere]]]]]]]

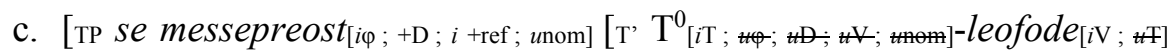
$\left[\nu \mathrm{p} \mathrm{t}_{\text {se messepreost }} \ldots\left[\right.\right.$ [ $\left.\left.\mathrm{t}_{\text {leofode }}\right]\right]$

In (18a) we can see that after the merger of DP and NP, se moves to [Spec, DP] to value $\mathrm{D}^{0}$ 's $[u+$ ref] feature. In (18b) we can see the outcome of the merger of the verb with the internal Prepositional Phrases be hläfe and be wotere 'on bread and water' and the subsequent merger of VP with $v^{0}$. The base-generation of se messeprēost ('the mass-priest') in [Spec, $v \mathrm{P}]$ is warranted because the $\mathrm{DP}$ bears the $[u]$ nominative Case feature and is, therefore, the subject. In $(18 \mathrm{c})$ we can see the merger of $\mathrm{T}^{0}$ with $v \mathrm{P}$ which is followed by the movement of the verb leofode ('lived') to $\mathrm{T}^{0}$ and the movement of se messeprēost to [Spec, TP]. Both movement operations are triggered by the $[u \mathrm{val}]$ features on $\mathrm{T}^{16}$. As regards the $[u$ nom] Case feature on the DP in [Spec, TP], it is valued configurationally in TP against $\mathrm{T}^{0}-$ its reflex being subject-verb agreement. This allows us to account for the position of topicalised constituents and the verb more effectively in examples where a non-subject XP targets some position above TP, but below CP. We will take this position to be Topic Phrase (TopP) hosting old

subject topics in [Spec, TP] and the verb in $\mathrm{T}^{0}$ (cf. Kroch \& Taylor 1997). Biberauer \& Roberts (2010), from whom we adopted the above feature distribution, assume a non-V2 word order, if $\mathrm{T}^{0}$ inherits $\varphi$-features from $\mathrm{C}^{0}$, as in ModE, and a V2 word order, if $\mathrm{C}^{0}$ keeps the $\varphi$ features, as in German or OE.

16 We take V-T movement as overt in OE without motivating it here. Such movement is often conflated with rich agreement or morphological distinction between the $1^{\text {st }}$ and $2^{\text {nd }}$ person in at least one number of at least one tense. Insofar as the analyses on OE show, it satisfies these requirements. See Pinker (1994), Rohrbacher (1994), Koeneman (2000), or Biberauer \& Roberts (2010) for discussion. 
information (e.g., Los 2012; Taylor \& Pintzuk 2014). In order to locate TopP in the clause structure we follow Rizzi's (1997) split-CP projection perspective ${ }^{17}$ :

(19) $\left[\right.$ Forcep $\left[\operatorname{Force}^{0}\left[\operatorname{TopP}\left[\operatorname{Top}^{0}\left[\mathrm{FocP}\left[\operatorname{Foc}^{0}\left[\mathrm{FinP}\left[\mathrm{Fin}^{0} \ldots\right.\right.\right.\right.\right.\right.\right.$

For the sake of clarity, we will label ForceP as CP because it is conflated with the projection that specifies the clause type (Rizzi 1997; Roberts \& Roussou 2002). Let us now examine the derivation of the V2 context represented in (20):

(20) a. TopP merges with TP

$\left[\right.$ TopP $\operatorname{Top}^{0}\left[{ }_{\text {TP }}\left[\mathrm{T}^{\prime} \mathrm{T}^{0}{ }_{\text {vP }}\right.\right.$ Gregorius $[i \varphi,+\mathrm{D}, i+\mathrm{ref}, \mathrm{nom}] \ldots\left[\right.$ sende $_{[i \mathrm{~V}, u \mathrm{~T}]}[\mathrm{PP}$ on his dagum $\left.\left.\left.\left.\left._{[i+\mathrm{ref}]}\right]\right]\right]\right]\right]$

b. CP merges with TopP $\rightarrow \mathrm{C}^{0}$ donates ${ }_{[i \mathrm{~T}, u \mathrm{~V}, u \varphi, u \mathrm{D}]}$ features to $\mathrm{T}^{0}$ and ${ }_{[u \mathrm{~V}]}$ feature to $\mathrm{Top}^{0}$

[CP $\mathrm{C}_{[u \mathrm{~T}, u \mathrm{~V}, u \varphi, u \mathrm{ref}, u \mathrm{D}, u \mathrm{nom}]}^{0}\left[\mathrm{TopP} \mathrm{Top}_{[u \mathrm{~V}, u+\mathrm{ref}]}\left[\mathrm{TP}^{0} \mathrm{~T}_{[i \mathrm{~T}, u \varphi, u \mathrm{D} u \mathrm{~V}, u \mathrm{nom}]}^{0} \ldots\right.\right.$

c. $\mathrm{T}^{0}$ probes and agrees with $\mathrm{V}$ and $\mathrm{DP} \rightarrow \mathrm{V}$ - and DP-movement to TP


dagum[i+ref]]]]]]

d. Top ${ }^{0}$ probes and agrees with $\mathrm{V} \rightarrow \mathrm{V}$-movement to Top ${ }^{0}$ [TopP Top ${ }_{[H \mathrm{H}, u+\mathrm{ref}]}-\mathrm{T}^{0}-\mathrm{V}_{[i \mathrm{~V}]}^{0}\left[\mathrm{~T}, \mathrm{t}_{\mathrm{T}-\mathrm{V}} \ldots\right.$

e. Top ${ }^{0}$ probes and agrees with $\mathrm{DP}_{[i+\mathrm{ref}]} \rightarrow \mathrm{DP}_{[i+\mathrm{ref}]}$ movement to [Spec, Top]



Example (20), which is simplified here (derivational steps up to the point of merging TP are omitted), represents the derivation of (17c). In OE, non-subject constituents such as on his dagum ('on his days') can move to TopP for discourse purposes. Gregorius located in [Spec, TP], and the verb in $\mathrm{T}^{0}$ agree in $\varphi$-features, which is manifested as verbal agreement, i.e., sende ('sentPAST.3SG'). This suggests that on his dagum must be above TP, because it does not agree with the verb and bears oblique Case uninterpretable in TP. As regards the verb, it is predicted to move to $\mathrm{Top}^{0}$ which has the $[u \mathrm{~V}]$ feature to value. The movement of on his dagum to [Spec, TopP], on the other hand, is triggered by the $[i u \mathrm{val}+\mathrm{ref}]$ feature on Top ${ }^{0}$. Because nouns are $[u+\mathrm{ref}]$, they are disregarded as potential goals, unlike demonstratives or pronouns which are $[i+\mathrm{ref}]$. This may imply that projections above TP which usually host topics or contrastive foci require a specific LI in order to be identified. Vangsnes (2002), for

17 There are other, more articulated cartographies of the Left Periphery (see Bech \& Salvesen 2014 for a brief overview). Also, topicalisation/focalisation does not have to introduce given/new information. Despite that, $\mathrm{CP}$ is often assumed to represent the information unit (Svenonius 2002: 231) which is anchored to the context (Roberts \& Roussou 2002). 
example, argues that identification takes place, if any constituent merged in TopP has, at least, one feature relevant for TopP. Following the approach employed in this paper, we propose that Case and gender are such features. This seems to be correct, if we consider that it is demonstratives and full DPs that shift topics in OE rather than bare nouns (with the exception of proper names which are referentially specific like demonstratives or pronouns - cf. Farkas \& de Swart 2007) ${ }^{18}$.

We have more to say about Case and gender features in discourse referencing contexts in the sections that follow. Before turning to the examination of the $\mathrm{OE}$ data, we first examine distribution and properties of German and Dutch demonstratives, which is dictated by the fact that their distribution and overt manifestation of nominal $\varphi$-features overlaps with the $\mathrm{OE}$ counterparts.

3.4.3. OE demonstratives: On the role of gender and Case in discoursereferencing

\subsubsection{Excursus on German and Dutch demonstrative pronoun properties}

As a first approximation, let us examine the differences between German personal and demonstrative pronouns in (21) (word by word glosses omitted for space reasons).

(21) a. Als Peter $r_{i}$ auf die Straße herauskam, begegnete er einem alten Freundj.



'When Peter stepped out on the street he ran into an old friend. Thisnom (one) said hello to him/This ${ }_{\mathrm{ACC}}$ (one) he said hello to.'

b. Als Peter ${ }_{i}$ auf die Straße herauskam, begegnete er einem alten Freund j. $_{\text {. }}$ $\mathrm{Er}_{\mathrm{i} / *_{\mathrm{j}}}$ grüßte den $*_{i j}$.

'When Peter stepped out on the street he ran into an old friend. He (one) said hello to the $\mathrm{ACC}$ (one).'

Personal pronouns like accusative ihn ('him') and nominative er ('he') in the clause-final position or er in the clause-initial position in (21b) maintain reference with the subject, while demonstrative pronouns like nominative der ('this (one)') do not. Abraham (2007: 41) and Hinterwimmer (2014) note that

18 One of the reviewers argues that [i] features are not prerequisite for movement in compliance with Chomsky's (2001) Activity Condition which states that inactive elements are not accessible for further operations. We discuss this issue in a separate section (4.2.3.) as it is too broad and complex to be dealt with in a footnote. 
this distinction makes German a discourse functional language in that " $D$ pronouns avoid antecedents that are discourse topics" (Hinterwimmer 2014: 7). Example (22) shows that it is not the clause function of a demonstrative or the linearly last position that becomes crucial in marking topic shift, but discourse function.

(22) [ст Nur wenige Reaktionen ${ }_{j}\left[{ }_{\text {IP }} t_{j}\right.$ registrieren $n_{k}$ die Beamten ${ }_{i}$ gestern [vp $t_{i} t_{j}$

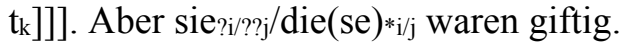

'Only few reactionsaCC.PL registered the officersNOM.PL yesterday. But they were venomous.'

The demonstrative co-refers with the sentence-initial DP nur wenige Reaktionen ('only few reactions'), which is an object acting as a comment on the subject die Beamten ('the officers'). While the personal pronoun er ('he') in the second clause in (21b) co-refers with a discourse-given constituent in the first clause, the accusative den ('the (one)') in (21a) refers only to a non-topical discoursenew antecedent. As can also be seen, in (21a-b) there is a sentence-initial topical constituent that opens up the second clause and functions as a link to previous discourse $^{19}$. This syntax-semantic property is available owing to morphological contrasts in Case and gender - forms like der, die, das are often termed as near articles (Wiltschko 1998; Millar 2000) because the definite article/ demonstrative function is not entirely separable.

In (23) below, it can be seen that Dutch organises reference across the clause boundary in a similar way to German, i.e., using demonstratives and personal pronouns. Below, die ('the (ones)') co-refers with the object antecedent:

(23) a. [We hadden vorige week logé's uit Limburg] en die waren zo enthousiast over Elburg.

Wir hatten vorige Woche Gäste aus Limburg, and (sic!) die(se)/*sie waren so begeistert über Elburg. (German)

'We had guests last week from Limburg, and the (ones) were so enthusiastic about Elburg.'

b. Is deze plaats vrij? - Dat geloof ik wel

is this place free that believe I

'Is this place free? I believe it is.'

19 As regards 'discourse-given' status, we take it to represent the entity that has already been mentioned. 'Discourse-new' entities, on the other hand, are those that have not yet been mentioned in the discourse. 
In (23b) dat ('that') is discourse-deictic (Diessel 1999: 101), because it does not refer to a nominal antecedent, but to a proposition is this place free?, as argued by Salverda (1982: 247). Although richness of gender contrasts between Dutch and German is considerable, distribution and properties of Dutch demonstratives mirror those in German. While German mostly retains division into, at least, two genders in the $[+\mathrm{Sg}]$ declension, Dutch has only neuter $d a t$ ('that') in $[+\mathrm{Sg}]$ and die ('those $[$ agender $]$ ') in $[-\mathrm{Sg}]^{20}$. Interestingly, such marginal contrast in Dutch suffices for reference across the clause boundary. Bohnacker \& Rosén (2007: 48) and Los (2012: 37-38) argue that gender contrast is vital for specific referencing, which is further strengthened by the fact that the common gender suffix $-e$ in Dutch attributive adjectives, when used in definite contexts, makes the use of the pro-forms like one in English unnecessary:

(24)

\begin{tabular}{l|l|l|l|l|l|l}
\hline welke & broek & trek & je & ann, & de & blauwe \\
\hline which & trousers & put & you & on & the & blue $_{I N F L}$ \\
\hline
\end{tabular}

'Which trousers will you put on, the blue ones?'

Apart from the above, there are other, equally important similarities between German, Dutch, and OE demonstratives. For example, not only do they switch topics, but they also occupy the initial pre-subject position where topicalised and/or contrastive foci are usually located. Moreover, German and Dutch demonstratives show the same syntactic heterogeneity as the OE ones, i.e., they can be used independently and as specifiers. In German, we could see this property in (21a-b). The same property in Dutch is shown in (25). In die lampjes ('those lamps'), the demonstrative is located in [Spec, DP]. The second die is used independently as a demonstrative pronoun located in $\mathrm{D}^{0}$ (Klijs 2013).

(25)

\begin{tabular}{l|l|l|l|l|l|l}
\hline al & die & lampjes & die & gaan & niet & meer... \\
\hline all & those & lamps & they & go & not & longer \\
\hline
\end{tabular}

'...all those lights, they don't go...'

20 The German demonstrative pronouns are: der ('the MASC'), die ('the FEM'), das ('the

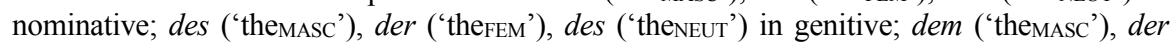

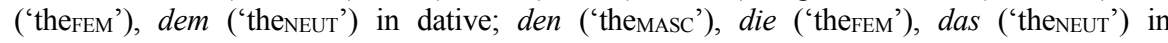
accusative in the singular declension. In plural there is no gender marking and the demonstrative pronouns show only Case-distinction into die ('the $\mathrm{NOM}^{\prime}$ '), der ('the $\mathrm{GEN}^{\prime}$ ), den

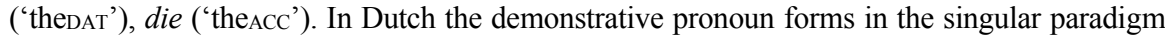

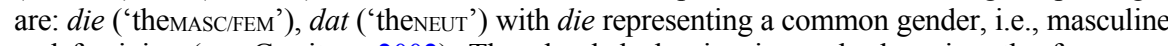
and feminine (see Gerritsen 2002). The plural declension is gender-less, i.e., the forms are specified as [agender]: die ('the'). 
3.4.3.2. On the properties of OE demonstratives in the clause-based perspective

The examples below show that demonstrative distribution and properties in $\mathrm{OE}$ are similar to those of German and Dutch ones.

(26) a. ('Who can know how many men were slain on both sides?')

\begin{tabular}{l|l|l|l|l|l}
\hline paet & Omarus & se & scop & sweotelicost & sægde \\
\hline thatoBJ & Homer & DEM & poet & most-clearly & spoke \\
\hline
\end{tabular}

'Homer the poet spoke that most clearly.' (Bech \& Salvesen 2014: 260, Or 31)

b. $=(1 \mathrm{a})$

\begin{tabular}{l|l|l|l|l|l|l|l}
\hline Ic & geseah & wingeard $_{i .}$ & On & pam $_{i}$ & waeron & III & clystru \\
\hline I & saw & vineyard & in & that masc $^{\prime}$ & were & three & vines \\
\hline
\end{tabular}

'I saw a vineyard. It had three vines/In it were three vines.' (Los 2012: 36, Gen (Ker) 40.9-10)

$\mathrm{c.}=(1 \mathrm{~b}),($ Ac gecuron him anne scop to cyninge of Atheniensem, and eft mid firde foran wip pa Messene. pa hi him nealcehtan, pa getweode hie hwoeder hie wið him moehten.)

\begin{tabular}{l|l|l|l|l|l|l|l}
\hline Se & heora & cyning & ongan & ða & singan & and & giddian \\
\hline SE & their & king & began & then & sing & and & recite \\
\hline
\end{tabular}

'(And they elected a poet from the Athenians as their king, and afterwards went out with a force against the Messians. When they approached them, then they doubted whether they would prevail against them.) That one, their king, began then sin and recite...' (Breban 2012: 279, Orosius, Bates, 14.35.12-4)

d.

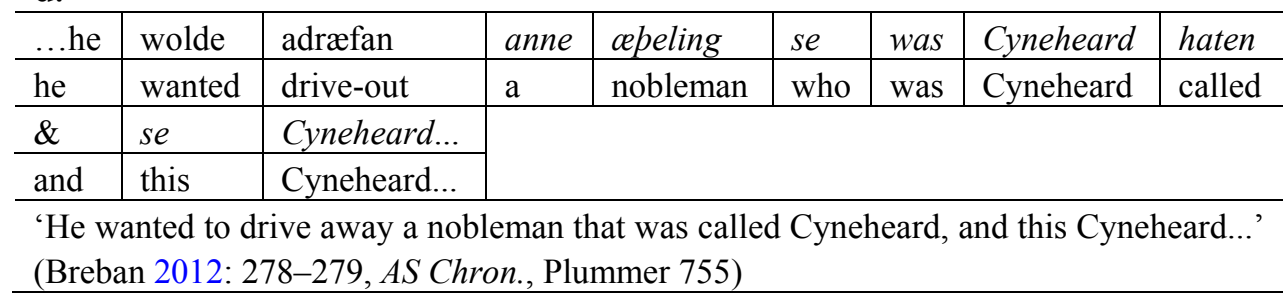

In (26a) the demonstrative is used discourse-deictically, and in (26b) the initial on pam ('in that') refers back to the object in the preceding clause ${ }^{21}$. Example (26c) shows the masculine se ('that') which co-refers with the object anne scop

21 OE demonstratives need not act as topic switchers and their pronominal instances need not continue topics, as noted by van Gelderen (2011a: 10). 
('a poet') in the preceding clause. In (26d), se is used in a non-identifiable context first (in the focalised constituent anne apeling se was Cyneheard haten 'a nobleman that was called Cyneheard'), and then it is topicalised in the second mention, i.e., se Cyneheard. In examples (26a-b), the demonstratives seem to occupy TopP, and in (26c-d) they can either stay in TP or move to TopP like oblique demonstratives, but the exact position is irrelevant here ${ }^{22}$.

Let us consider examples (26a-b) in more detail. In the two examples, the demonstratives are topicalised for the purpose of information structuring - the initial lexical material is discourse-given and followed by the verb in Top ${ }^{0}$ which is a syntactically second position in the clause (26b). In (26a), paet is followed directly by the subject in [Spec, TP]. With the two examples in mind, let us represent the topic shift property in OE schematically, as in (27).

\section{(27) Topic Shift}

[Clause1 [Theme WP ... [Rheme $\mathrm{XP}_{\mathrm{i}} \ldots$ [Clause2 [Theme $\left[\right.$ Rheme $\left.\left.\mathrm{YP}_{\mathrm{i}}\right]\right] \ldots$ [Rheme ZP ... tYP ]]]]]]]

Topic shift also co-exists with another property of local anchoring to the context. The former instigates the latter in that anchoring always targets the first position in the clause where OE, German, or Dutch usually feature temporal adverbs for time setting or adverbs of place for space setting (28a-b). Example (28c) shows the schematic representation of local anchoring in OE.

(28) a.

\begin{tabular}{l|l|l|l|l|l|l|l|l}
\hline Dann & & wird & er & plötzlich & von & dem & Brett & geweht \\
\hline then & & will & he & suddenly & from & the & board & thrown \\
\hline
\end{tabular}

b.

\begin{tabular}{l|l|l|l|l|l|l}
\hline$p a$ & siglde & he & ponan & suðryhte & be & lande \\
\hline then & sailed & he & from.there & southwards & along & coast \\
\hline
\end{tabular}

'Then he sailed from there southwards along the coast.' (Eitler \& Westergaard 2014: 205, Or 14:16

c. local anchoring $=(26 b)$

[Clause1XP YP $\underbrace{}_{i}\left[\right.$ Clause2 $|\underbrace{\text { Local anchor On } \text { pam }_{i}}|$ waeron III clystru ti

22 We assume, after van Kemenade \& Westergaard (2012: 98), that whenever se is discoursegiven, it occupies the higher position and when it is discourse-new it is in [Spec, TP]. 
Whenever the oblique DP, demonstrative, or a prepositional phrase is in TopP and values the $[i+\mathrm{ref} / \mathrm{spec}]$ feature, it is in a position where it becomes PF- and LF-interpretable owing to the presence of $[i]$ Case and gender features. This provides the link to previous discourse and additional pieces of information about the action denoted by the predicate. For example, in (28a) the initial adverb provides the time-setting of the event - it adds something about the time in which the event takes place. In (26a), poet tones down the role played by the subject, i.e., the main protagonist, as defined by Stutterheim \& Carroll (2005). The same effect is obtained by on pam in (26b) - it becomes the centre of attention because it relates directly to the previous mention of wingeard ('vineyard') and so the piece of discourse information revolves around the object rather than the protagonist.

\subsubsection{OE demonstratives: Case, gender, and discourse-linking}

In this section we will briefly account for the properties characteristic of the $\mathrm{OE}$ demonstratives that have been shown in the previous section. The cornerstone of the examination is morphologically manifested Case and gender features.

Below we represent the details of the anaphoric relation between the demonstratives and their antecedents. For the purpose of examination we reconsider examples (26b) and (26c), discussing the former first.

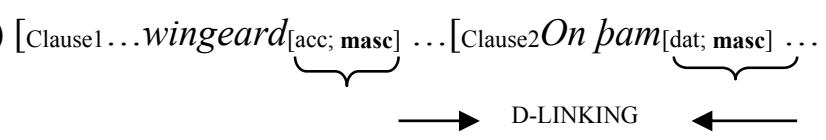

In (29), wingeard and pam are used in the singular and manifest the same gender. Despite some syncretism (e.g., masculine/neuter and nominative/accusative), the appropriate Case and gender will be specified, because these forms can be learned on the basis of paradigm-internal contrasts (Koeneman 2000: 78) and their distribution. The arrows signal that each LI is a 'center of attention' which 'retains the reader's/listener's focused attention for a certain textual period" (Abraham 2007: 24). It could be proposed that specific reference between the noun and the demonstrative equals matching of the gender feature and the syntactic relation of the type [rheme $\rightarrow \leftarrow$ theme] encoded by the Case form the two constituents carry. A good example of how it works is to re-consider the German (21a) which features gender dissociation between accusative alten Freund ('old friend') and der/den ('the NOM/ACC'). It is the accusative Case and masculine gender shared between Freund and den that yield unambiguous referencing. The same pattern re-appears in OE (26a-b). In the former example, the dative pam ('that') in the second clause narrows down 
and specifies the context in which it is used to [masculine, dative, $+\mathrm{Sg}$ ] due to the rich information content it carries. Because the antecedent noun wingeard also carries the $[i]$ masculine gender feature, the two co-refer when the matrix clause is introduced. As for the richly manifested Case system, it provides unambiguous information about the grammatical status of the DP to which the demonstrative refers. This is articulated even more so, if TP is represented configurationally as the projection where tensed proposition of the clause is formed - oblique DPs, adverbials, or wh-constituents will have to occupy some pre-TP position for reasons already discussed. Let us now consider example (26c) represented below in (30).

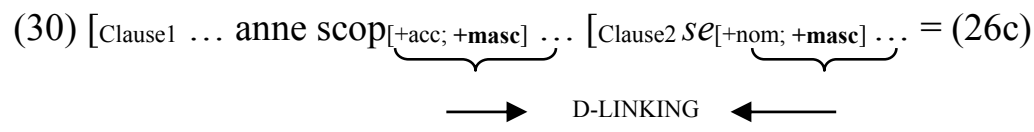

The noun scop ('poet') and the demonstrative se ('the') are used in the masculine context and in the singular. Again, there is some Case indeterminacy in the noun's form, i.e., [nominative/accusative], but the appropriate Case will be specified owing to the richness of the contrasts in the nominal paradigm and the position the noun occupies in the clause. Specifically, anne scop is a verbinternal argument and, therefore, a comment on the topic him ('they'). The nominative and masculine se two clauses later looks for an antecedent to refer to, but there is no appropriate one in the second clause - neither the plural $p a$ ('the') nor pronominal $h i$ ('they ${ }_{\mathrm{NOM}}$ '), and him ('them ${ }_{\mathrm{ACC}}$ '). Because se shifts the topic in this context, the nominative $h i$ is out, as is him which is plural and has no gender feature to match. The only possible candidate is scop in the first clause whose accusative Case and masculine gender allow for specific reference between the two LIs to hold.

Although the above remarks are perfunctory, what they indicate is that gender and Case in OE should be considered to be interface features that have an impact on derivation and on the positive satisfaction of the FI requirement ${ }^{23}$. With respect to the above remarks, the question that remains to be answered is what effects the levelling of morphology has on syntactic distribution and discourse properties of the (E)ME demonstratives.

23 Let us emphasize that we are talking here about grammatical/formal gender - pure morphology which, along with Case, lexicalises the category of definiteness. Thus, the gender feature does not map onto semantically relevant features, but gives value to another feature (Josefsson 2013; Citko 2014: 16-17). 
4. On the formal and pragmatic properties of (E)ME demonstratives

\subsection{Morphological contrasts in Case and gender}

The ambiguities in gender and Case, as observed in OE, continued to spread over the demonstratives in EME. Despite that, Brunner (1963), Fisiak (1968), and Allen (1995) note that the inflectional system of the EME se demonstratives of Southern and Western texts at the beginning of the $13^{\text {th }} \mathrm{c}$. still distinguishes Case and gender (Brunner 1963: 62):

Table 2. ME se-demonstratives inflections in Southern \& Western texts

\begin{tabular}{|c|c|c|c|c|}
\hline \multicolumn{4}{|c|}{ Singular } & Plural \\
\hline Case & Masculine & Feminine & Neuter & all genders \\
\hline Nominative & pe & peo & pat & pa \\
\hline Genitive & pes, peos & pære, pere, pare & pæs & pere \\
\hline Dative & pan, pane & pære, pere, pare & pǣm & pam \\
\hline Accusative & pan, pane & - & pæt & $\mathrm{pa}$ \\
\hline
\end{tabular}

The nominative singular context in all genders shows no initial $-s /-b$, as was the case in OE. Brunner (1963: 62) indicates that the $-s$ has been levelled out, while se/seo remained as vestiges of the old D-system only in texts from the transition period. The invariable $p e$, as argued by Millar (2000), is the outcome of a phonetic attrition process. The loss of the final $-e$ in the accusative pone caused levelling with the dative $\mathrm{poem}$, leading to the emergence of $\mathrm{pan} / \mathrm{bon}$ which, after merging together, were confined to dative/accusative contexts. Further erosion of the final $-n$ has, ultimately, produced $p e^{24}$. Let us now consider the innovative se demonstrative system in Vices and Virtues (Malak 2008: 190):

Table 3. Innovative se-D-paradigm in Vices and Virtues ${ }^{25}$

\begin{tabular}{lcccc}
\hline \multicolumn{4}{c}{ Singular } & Plural \\
\hline Case & Masculine & Feminine & Neuter & all genders \\
Nominative & pe & pe & pe & pe \\
Genitive & pas, pes & pare, pa & pas, pes & pare \\
Dative & pe & pe & pe & pe \\
Accusative & pe & pe & pat & pe \\
\hline
\end{tabular}

24 The levelling of final vowels was characteristic also of nominative contexts featuring pe, peo and the $[-\mathrm{Sg}] p a(b \bar{a}-$ Brunner 1963: 62) where the final unaccented vowel was especially prone to erosion and promotion of pe as a default option (Millar 2000: 334).

25 The Vices and Virtues text has been dated variously - between 1200-1225 (Trips 2002), the beginning of the $13^{\text {th }}$ century (Laing 1993), or the end of the $12^{\text {th }}$ century (Hall 1920). 
Here, the levelling is much more advanced than in Southern and Western texts. The only context still marking gender is [genitive, $\pm \mathrm{Sg}$ ]. Also, as in $\mathrm{OE}$, the [-Sg] contexts are gender-less in EME. As for Case, it is poorly marked on masculine and feminine demonstratives in $[+\mathrm{Sg}]$, although genitive is still disambiguated from the remaining Case forms in $[ \pm \mathrm{Sg}]$, which would allow us to postulate the genitive gender feature in the innovative paradigm ${ }^{26}$. Further erosion of inflectional endings on the EME demonstratives was (largely) completed by 1150 in the East and North, and by 1250 in the South (Brunner 1963: 62). Fisiak (1968: 84) claims that by the end of the ME period (before 1450) the inflectional distinction in se demonstratives was lost completely (cf. Markus 1995). With regards to the above, it may be expected that the appearance of the uniform pe brought about a series of important side effects. Because the minimal amount of morphologically-distinct forms required to postulate a given feature is two, which yields $[\alpha \mathrm{F}]$, pe becomes unspecified for any feature.

\subsection{On formal and pragmatic changes in the EME demonstratives}

The fact that $p e$ does not manifest any nominal $\varphi$-features implies that it cannot participate in feature valuation with $\mathrm{D}^{0}$ and Top ${ }^{0}$ because it lacks $[i]$ Case and gender features - their demise means shifting the $[+$ ref] feature from the formal to the semantic pole. An equally important side effect has to do with a movement-triggered feature valuation that becomes lost, which presupposes a direct merge of $p e$ in $\mathrm{D}^{0}$. Once this becomes the only possibility, pe loses its syntactic heterogeneity and, confined to a fixed position in DP, becomes a compulsory constituent. We could consider that moment as the point of becoming a definite article. An aftermath of the above changes is that $p e$ 's $i / u \varphi$ features become $[u]$, which presupposes the loss of some pragmatic properties too $^{27}$. Summing up the above remarks, we could represent the syntactic restructuring of $p e$ in (31a-c).

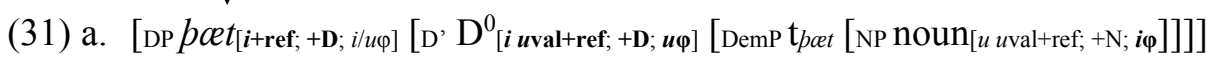

26 It may be assumed so because of the similarity of the genitive forms like pas and pes leading to the leveling as in the case of $p e, p e o$ and $p a$. In feminine contexts the situation is more difficult because pare can surface in $[+\mathrm{Sg}]$ and $[-\mathrm{Sg}]$, surrounded by $p e$. In this context, the $[ \pm \mathrm{Sg}]$ opposition would be harder to establish than in [masculine/neuter] contexts.

27 The $u \varphi$-features on $p e$ are [uval], i.e., they need to be valued against [val] counterparts on the noun. After that, they become instances of $[u$; val] features marked for deletion before they reach the system(s) of semantic interpretation (Bošković 2011). 


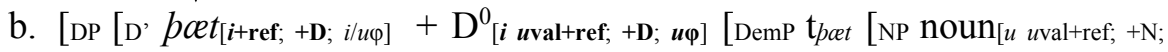
$i \varphi]]]]$

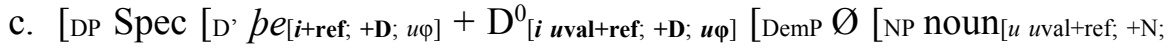
$i \varphi]]]]$

Examples (31a-b) show demonstratives that can occupy the specifier or head position in DP, depending on the semantic property they convey. In (31c), we can see the (E)ME stage after the abovementioned changes have taken place. The (E)ME $p e$ is now confined to occupy a fixed position in $\mathrm{D}^{0}$. Due to its feature matrix being $[i u v a l+r e f ;+\mathrm{D} ; u \varphi], \mathrm{D}^{0}$ agrees with the $\mathrm{NP}$ for $i \varphi$-features and values its $[u \mathrm{val}+\mathrm{ref}]$ feature against the valued counterpart on pe merged as a DPhead. Prior to this valuation step, $p e$ is $\varphi$-complete (but see below) because it shares these features with the NP. Bearing in mind that TopP carries an inherent [ $i \quad u \mathrm{val}+\mathrm{ref}]$ feature, the syntactic reorganisation schematised above will have consequences for topicalisation too. When Case and gender features become absent from derivation, feature valuation between $\mathrm{Top}^{0}$ and $p e$ is impossible because the latter loses its pronominal property (were it to move to TopP, it would be unable to receive an interpretable representation at the interfaces). In accordance with earlier remarks on feature distribution, Top $^{0}$ will probe $b e$ for the $[i+$ ref $]$ feature, but $p e$ is now unable to move there on its own, even though it is $\varphi$ complete. As noted above, once (E)ME demonstratives lose Case and gender morphology, their $\varphi$-features become $[u]$ and hence, the only available movement option for $p e$ is to pied-pipe the NP complement whose [i] $\varphi$-features will allow the topicalised constituent to satisfy $\mathrm{FI}^{28}$. Interestingly, the distal demonstrative in (33) can be topicalised independently due to its morphological and formal opposition:

(32) [As it is by the woman and her mirror; she beholds her mirror, and her shadow cometh thereon. $]^{29}$

\begin{tabular}{l|l|l|l|l|l|l|l|l|l|l}
\hline pe & shadewe & hire & tacheð & hwu & hie & mai & hire & seluen & wenlukest & makien \\
\hline the & shadow & her & teaches & how & she & can & her & self & $\begin{array}{l}\text { most } \\
\text { lovely }\end{array}$ & make \\
\hline
\end{tabular}

'and the shadow teaches her how she can make herself look most lovely.' (Homilies, 29)

28 The agree operation between $\operatorname{Top}^{0}$ and $p e$ that values the former' $[u$ val + ref $]$ feature is perfectly licit in and of itself. The NP pied-piping option is required by the movement operation and has to take place before the NS-derived lexical material is sent to the semantic system(s).

29 The translation of the context comes from The Lord's Prayer, Morris (ed.), (1873: 29). 
(33) [and on his left hand an accursed spirit that ever teacheth him to evil]

\begin{tabular}{l|l|l|l|l}
\hline and & pat & is & pe & deuel \\
\hline and & that & is & the & devil \\
\hline
\end{tabular}

'and that is the devil' (Homilies, 11)

Summing up, the EME pe differs formally from its OE counterparts. While it can still be used for anaphoric referencing when followed by an NP, it loses its pronominal property due to gender and Case indeterminacy. The loss of grammatical gender and Case is then tantamount to shifting the [+ref] feature on pe from the formal to the semantic pole. Consequently, the distribution of $p e$ becomes narrower and motivated syntactically rather than pragmatically.

\subsubsection{Pronominal use of $p e$ and non- $p e$ forms from $\mathrm{LOE}$ to $\mathrm{EME}^{30}$}

That the above reasoning is on the right track seems to be supported by the data from the texts produced during the transition period between $\mathrm{OE}$ and EME (roughly from 950 to 1350). In Table 4 we show the distribution of pe and nonpe forms in pronominal contexts - the texts are in the chronological order, i.e., from the oldest to the earliest. The brackets next to demonstratives indicate the overall number of a given form, while numbers without brackets indicate the pronominal instances of a given form. Only the $[+\mathrm{Sg}]$ contexts are included. Due to numerous vowel combinations, the ' $V$ ' letter represents any such combination. As for Case distinction, both preposition-less and prepositional contexts are included.

Table 4. $p e$ and non- $p e$ forms used pronominally between LOE to EME ${ }^{31}$

\begin{tabular}{c|c|c|c|c|c|c|c|c}
\hline Text & \multicolumn{5}{|c|}{ non- $p e$ forms } & \multicolumn{4}{|c}{$p e$ forms } \\
\hline LGs & NOM & ACC & GEN & DAT & NOM & ACC & GEN & DAT \\
& se (94) 88 & $\partial a(38) 9$ & $\partial V s$ & $\partial V m(53) 9$ & $\partial e(4)-$ & $\partial e(3)-$ & - & - \\
& $\partial V t(13) 2$ & $p V t(13) 1$ & $(35) 3$ & $\partial V r e(11) 1$ & & & & \\
PC & $p V t(1) 1$ & $\partial V n e(43) 1$ & & & & & & \\
SI & $p V t(9) 1$ & $p V t(5) 2$ & - & $p V n(5) 2$ & $p e(34)-$ & $p e(15)-$ & - & $p e(47)-$ \\
\hline
\end{tabular}

30 All the quantitative data are adapted from Millar (2000).

31 The text title abbreviations are: LGs - English gloss to the Lindisfarne Gospels; PC - Second Continuation of the Peterborough Chronicle; SI - Seinte Iuliene (Bodleian Library); SK Seinte Katerine (Cotton MS Titus D); VV - Vices and Virtues; LB - Lazamon's Brut; SEL South English Legendary. 


\begin{tabular}{|c|c|c|c|c|c|c|c|c|}
\hline SK & $p V t(5) 4$ & $p V t(19) 6$ & - & & pe (64)- & pe (37)- & - & pe (55)- \\
\hline VV & $\begin{array}{l}s e(43) 35 \\
p V t(31) 9\end{array}$ & $p V t$ (36) 10 & - & $p V t(5) 3$ & ðе (92)- & ðе(53)- & - & ðе (77) - \\
\hline LB & $p V t(295) 20$ & $\begin{array}{l}p V n(48) 12 \\
p V t(268) 52\end{array}$ & & $\left|\begin{array}{c}p V n(905) 2 \\
p V t(11) 2\end{array}\right|$ & pe (1356) - & pe (67)- & - & pe (16) - \\
\hline SEL & $p V t$ (46) 2 & $p V t(59) 8$ & & $p V t$ (15) 8 & pe (298) - & pe (198)- & - & pe (294) - \\
\hline
\end{tabular}

What Table 4 shows is that no matter the date of the composition of a particular text or the Case/gender form of a demonstrative, the pronominal use is found only amongst non- $p e$ forms. None of the $p e$ instances represented in the table is used independently regardless of the structural position in which it is used. In this respect, VV is especially telling. Allen (1995) argues that it features two D-systems - one conservative (retaining considerable amount of inflectional endings) and the other innovative (obliterating most of Case, gender, and number endings). Crucially, se represents the conservative system individuating between se in masculine/neuter contexts and pat in neuter contexts, amongst others (Allen 1995: 190) ${ }^{32}$.

\subsubsection{The demise of formal gender and Case features on demonstratives}

The data presented in the previous section seem to indicate that at least minimal distinction into Case or gender is necessary for a demonstrative to manifest the pronominal property.

(34) a.

\begin{tabular}{l|l|l|l|l|l|l|l}
\hline Ic & geseah & wingeard $_{i}$ & On & pam $_{i}$ & waeron & III & clystru \\
\hline I & saw & vineyard masc & in & that $_{\text {masc }}$ & were & three & vines \\
\hline \\
'I saw a vineyard. It had three vines/In it were three vines.' (Los 2012: 36, Gen \\
(Ker) 40.9-10) \\
?
\end{tabular}

32 The extensive use of pronominal se-forms in VV and LGs may be caused by the considerable extension of the forms' semantic specialisation (Millar 2000: 325-330) similar to that of pe (e.g., the use with non-historical gender forms or number, but also in historical contexts already in LOE which normally expected other forms like poes, for example - cf. Gelderen 2011a). Millar speculates that this specialisation might have been due to considerable influx of pe used in the same contexts as se apart from the pronominal one in which se was used exclusively. The next possible factor could have been the retention of the initial $-s$ contributing to the unique status of se similarly to poet. 
b. [South of that (city of) Skirings-salr a large sea runs up inland;]

\begin{tabular}{l|l|l|l|l|l|l|l|l}
\hline seo & is & bradre & ponne & æni 3 & mann & ofer & seon & mæ3e \\
\hline it $_{\text {fem }}$ & is & broader & than & any & man & over & see & may \\
\hline
\end{tabular}

The two oblique demonstratives refer back to non-topical DPs in the previous clause with which they also agree in gender. We could say that in (34a-b), the demonstratives lexicalise definiteness pragmatically by locating the relevant entity in the immediately preceding discourse (cf. Diessel 1999; Lyons 1999). In other words, the (in)definiteness status of the antecedent and the anaphor is relational and may be represented as [Clause1 $\ldots X_{i} \leftarrow$ [Clause2 $Y_{i} \ldots$ ty ] ] where $X$ is the first mention, and $\mathrm{Y}$ is the second mention of the entity. What relational implies is that co-reference between the two constituents is obtained on the same (syntactic) level, i.e., $\mathrm{X}$ is relationally new to $\mathrm{Y}$, while $\mathrm{X}$ is relationally old to X.

Let us now consider the syntactic perspective on the loss of formal gender and Case features, with the main point of interest being the distinction into nominative and oblique Case, and the fact that the former is established configurationally in TP. What it implies is that oblique DPs target some position above or below TP, co-referring with non-topical antecedents. Nominative demonstratives (e.g., se), on the other hand, continue sentential topics, i.e., main protagonists across longer textual spaces as in ( 35 - previous topics bolded).

(35) [Then looked he (the king) to one of his men, and said, "Go and find out what the young man is who to-day so well obeyed me." The man then went after Apollonius. When he saw that he was clad with a squalid cloak, then returned he to the king, and said, "The young man after whom thou askedst is a shipwrecked man." Then said the king, "Through what knowest thou that?] ${ }^{33}$

\begin{tabular}{|c|c|c|c|c|}
\hline Se & $\operatorname{man}$ & him & andswerode & [and cwæð: . \\
\hline the NOM & $\operatorname{man}_{N O M}$ & him $_{D A T}$ & answered & [and said: ... \\
\hline
\end{tabular}

'The man answered him [and said: ...] (Bech \& Salvesen 2014: 240, ApT 22)

The third person masculine se continues previous topics because Case and gender features of the subsequent referent mentions, i.e., the man, he, and se man contribute to unambiguous semantic interpretation. The same mechanism characterises the relation between previous comments and oblique

33 The translation of the context has been extracted from the resources of the University of Georgia at http://www.westga.edu/ mcrafton/white/formhel.htm (Apollonius of Tyre, verse $\mathrm{XX)}$. 
demonstratives (e.g., (34a) above). When morphology becomes lost, topic shift is unavailable owing to the fact that there are no contrasts like $p c e(-s /-m)$ between genitive and dative forms in $[+\mathrm{Sg}]$, for example. Consequently, (E)ME will feature no correlative constructions as the OE ones in (36-38), because the indeterminacy of $p e$ makes it unable to reflect the structural relation it has with the remaining constituents in the sentence.

(36) $[\ldots$ anne scop $\ldots[\mathrm{Se} \ldots]=(26 \mathrm{c})$

(37) $[\ldots$ wingeard ... [ $[(\mathrm{On})$ pam ... $]=(26 \mathrm{~b})$

(38) $[$ Eneas ... [ $\mathrm{Se} \mathrm{\ldots ..]}=(16 \mathrm{~b})$

The pre-subject position becomes available for $p e$ only if it is followed by a nominal, which becomes a rule since (E)ME. As before, Top ${ }^{0}$ still probes just for $p e$ because it bears the $[i+$ ref] feature. This step mirrors the one in $\mathrm{OE}$, but here it leads to the crash at the interfaces because $p e$ also bears $u \varphi$-features. The pied-piping option, whereby the NP complement moves together with $p e$ is the only way to make the sentence-initial topic interpretable at the interfaces:

(39) $\left[\ldots\right.$ her shadow ... [ pe $\left.\left.\left[\begin{array}{c}\text { aCase }] \\ {[\text { shadewe }[i \varphi])}\end{array}\right) \ldots\right]\right]=(32)$

One example in which such pied-piping takes place is (40) where pe deofel ('the devil') is, most probably, in TopP being discourse-given and reactivated (the previous mentions appear one page earlier).

(40)

\begin{tabular}{l|l|l|l|l|l|l}
\hline pus & pe & deofel & wulde & bilesnien & pe & wreche. \\
\hline thus & the & devil & will & destroy & the & wretch \\
\hline
\end{tabular}

'thus, the devil will destroy the wretch' (van Kemenade \& Westergaard 2012: 98, CMLAMBX1,23.257)

Despite the fact that topic shift declines from the (E)ME period onward, and so does the deictic property of the (E)ME D-system, it is still easy to find examples with topicalised objects represented by demonstratives such as pis ('this').

(41)

\begin{tabular}{l|l|l|l|l|l}
\hline pis & ne & habbe & ic & nauht & ofearned \\
\hline this & not & have & I & not & earned \\
\hline 'this I have not earned.' (van Kemenade \& Westergaard 2012: 98, \\
CMVICES1,17.192)
\end{tabular}


Another example is (33), repeated here as (42) which features the distal demonstrative pat ('that'):

(42)

\begin{tabular}{l|l|l|l|l}
\hline and & pat & is & be & deuel \\
\hline and & that & is & the & devil \\
'and that is the devil' (Homilies, 11) \\
' Hong
\end{tabular}

For Bech (2012: 39), it is the inherent contrastive sense of demonstratives that allows for topic shift. While pis and pat disambiguate between the [ \pm proximal] properties, this does not affect the proposal offered in this paper. The split into definite article $p e$ and proximal/distal demonstratives has already taken place and the above forms belong now to different paradigms (see also below) ${ }^{34}$.

With respect to the above, let us consider (43a-b), which feature the OE $[-\mathrm{Sg}]$ demonstratives used pronominally and manifesting only Case.

(43) a. [Then King Alfred ordered long ships to be built to battle the (Danish) warships;]

\begin{tabular}{l|l|l|l|l|l|l|l|l}
\hline $\boldsymbol{p a}$ & wæron & fulneah & tu & swa & lange & swa & pa & oðru; \\
\hline they & were & nearly & twice & as & long & as & the & others \\
\hline
\end{tabular}

'they were almost twice as long as the others' (850-950 ChronA, 90)

b. [When I reflected on all this, I recollected how - before everything was ransacked and burned - the churches throughout England stood filled with treasures and books. Similarly, there was a great multitude of those serving God. $]^{35}$

\begin{tabular}{l|l|l|l|l|l|l}
\hline$\&$ & $\underline{\boldsymbol{a}}$ & swiðe & lytle & fiorme & ðara & boca \\
\hline and & they & received & little & benefit & the & books \\
\hline
\end{tabular}

'and they received very little benefit from the books...' $(C P, 5)$

In the two examples, the [-Sg] $p a$ ('these (ones)/those (ones)') still trace back the antecedent even though they do not manifest gender. In (43a), the anaphoric relation between the demonstrative and the nominal in the preceding clause holds due to the organisation of lexical material ${ }^{36}$. The initial nominative $p a$

34 According to Brunner (1963), inflectional levelling in the OE se paradigm was largely completed by 1150 (East and North), while both pis and pat largely represent proximal and distal properties, respectively, by the end of the $12^{\text {th }}$ century (Fulk 2012: 68).

35 The ModE translation comes from Billet (2014: 136). Note that the OE counterpart of 'those serving God' is Godes Jiowa, i.e., ('God's servants'), which suits the examination purpose better than the pronominal those.

36 In (43a) the clause preceding the bracketed one tells about enemy bands on ships on which they plundered East Anglia and Northumbria. In the bracketed clause the focus shifts to long 
('those') is a second mention of long ships, and the linking between the two is secured by the repetition of the adjective long which predicates the property of the English ships in the two clauses. In (43b), the initial nominative $p a$ (those') points back to the servants of God in the previous clause. As in the former example, the use of the $[-\mathrm{Sg}] p a$ shifts the topic because it agrees in number with 'servants' (Jiowa in the original), and, most importantly, it bears the nominative Case. As witnessed earlier, it is the Case distinction that accounts for the grammatical role the demonstrative shows in the sentence. In the two examples above, the nominative demonstratives become logical-semantic subjects and topics by virtue of triggering the plural agreement on the verbs. On the contrary, the dative para ('those (ones)') can only function as a topic because it surfaces above TP. This is strengthened by the fact that para is followed by the verb and the nominative subject - the latter two agreeing in $\varphi$-features with each other.

(44) [The enemy had not, by the mercy of God, entirely crushed the English altogether, but they were afflicted much more in those three years by pestilence of cattle and of men; most of all among them many of the best of the king's thanes who were there in the land died within those three years $]^{37}$

\begin{tabular}{|c|c|c|c|c|c|c|}
\hline Para & wæs & $\underline{\text { sum }}$ & $\underline{\text { Swiðulf }}$ & biscop & on & Hrofesceastre... \\
\hline of these & was & one & Swithwulf & bishop & in & Rochester... \\
\hline
\end{tabular}

From the examination of the $\mathrm{OE}$ and (E)ME data presented above, it may be concluded that $[ \pm \mathrm{Sg}]$ OE demonstratives can surface independently and act as topic shifting devices due to formally manifested gender and Case features. While the former establishes specific reference, the latter specifies the grammatical relation between constituents in the sentence. We could propose that the OE demonstratives are not only discourse markers, but also a reliable extension of the Case and gender marking of nominals. Once the two features are lost, the determiner surfaces as Case-less and gender-less pe whose $u \varphi-$ features make it unable to agree with $\mathrm{Top}^{0}$ independently. As exemplified above, the only available option to host a pre-subject topic is to employ the pied-piping option whereby pe moves to [Spec, TopP] along with the NP complement which possesses $i \varphi$-features ${ }^{38}$.

ships to be built against the Danish ones.

37 The ModE translation of the context has been extracted from the University of Texas at Austin website http://www.utexas.edu/cola/centers/lrc/eieol/engol-5-X.html.

38 One of the reviewers raises the question of how the ModE full DPs like 'These lousy books 


\subsubsection{Some remaining problems}

Before we conclude the above examination, two problematic issues need to be tackled - one being the apparent problem with the phase-based derivation of oblique DPs that surface in TopP, and the other related to formal-pragmatic properties that separate the $\mathrm{OE}$ demonstratives and personal pronouns. We turn to the former issue first, since it is directly related to the topic of the paper.

The problem raised by one of the reviewers is that $[u, u v a l]$ gender and Case features on oblique demonstratives/DPs are deleted before the phase derivation of $v \mathrm{P}$ ends, which means that $\mathrm{Top}^{0}$ will not 'see' them before deletion takes place. These constraints, however, operate on two questionable notions, (at least with respect to rich agreement languages), that is Case (un)interpretability (Chomsky 1995) and Valuation/interpretability Biconditional (Chomsky 2001). As regards the first, Case features are $[u]$ and must be valued so that the derivation does not crash at LF. This seems to reflect the status of Case in ModE in which DPs are Case-less and show no information whatsoever as to the $\theta$-role they carry or the relation to other constituents they are in. Thus, the valuation of $\left[\begin{array}{ll}u \mathrm{val}\end{array}\right]$ Case features in ModE depends on syntax-internal operations and constraints, and is obtained as a 'by-product' of the Probe-Goal relation (cf. Nevins 2004; Danon 2011).

As regards the latter notion, it says that $[u \mathrm{val}]$ features are $[u]$, which, as already noted, works well in ModE. Interpretability of features equals valuation because syntax 'does not see' which LIs are going to be $[i]$. What matters is that a [uval] feature receives [val] before reaching the level of semantic interpretation. Crucially, according to Activity Condition (Chomsky 2001), only a Goal with $[u \quad u \mathrm{val}]$ features is visible for Agree, which also means that it becomes inactive when all such features are valued. These constraints seem to be ineffective in OE, Polish, Icelandic, or Russian, i.e., languages with rich agreement systems. In the above discussion, it has been shown that Case and gender features on the $\mathrm{OE}$ demonstratives are $[i]$, because they contribute semantically to the interpretation of the DP, unlike in ModE where the is a grammaticalised definite determiner. Let us consider several examples where Activity Condition is clearly violated, but the grammatical status is perfectly fine.

they would never read!' can still be legitimate topics despite showing no gender and Case morphology. Proximal and distal demonstratives shown above seem to corroborate the viewpoint that topicalisation is not determined by gender or Case as the only formal criteria Rather, it is connected with the minimal contrast in any formal feature - $[ \pm$ proximal $]$ or $\left[{ }^{\mathrm{sg}} \mathrm{s}\right]$, for example (cf. Los 2012). The fact that 'any feature' transcribes to gender and/or Case, as regards the $\mathrm{OE}$ demonstratives, does not undermine the point argued here. 
(45) (Russian)

\begin{tabular}{|c|c|c|}
\hline Soldat & ranilo & puljami \\
\hline soldiersACC & wunded $_{3 \text { SG.NEUT }}$ & bulletsINSTR \\
\hline
\end{tabular}

(46) (Polish)

\begin{tabular}{l|l|l}
\hline Jemu & brakuje & chleba \\
\hline him & lackPRES & bread $_{\text {GEN }}$ \\
\hline \multicolumn{2}{|l}{ 'He lacks bread.' } \\
\hline
\end{tabular}

(47) (Icelandic)

\begin{tabular}{|c|c|c|c|c|c|c|}
\hline Harald $_{i}$ & heldur & María & að & Jón & treysti & $t_{i}$ \\
\hline Harald $_{\mathrm{DAT}}$ & thinks3SG & Mary & that & Jón & trusts & \\
\hline
\end{tabular}

(48) (OE)

\begin{tabular}{l|l|l|l|l|l}
\hline him & engla & god & naman & niwan & asceop \\
\hline him & angels & god & name & new & created \\
\hline
\end{tabular}

'The god of angels created a new name for him.' (Malak 2008: 152, Exodus 380)

In example (45), there is no subject to agree with the verb, but the accusative DP still moves to a pre-verbal position to satisfy the EPP condition of TP (cf. Lavine \& Freidin 2002; Nevins 2004; Nossalik 2005). In doing so, however, it has already valued its Case feature and should be unable to take part in any other operation. In (46), we can see an example of a Polish verb that does not allow for a subject (cf. Tajsner 1998), but still does not ban a pre-verbal object that should be inactive having already valued its $[u$ val] Case feature. In (47), the extraction of the dative object Harald out of a $w h$-island is licit, even though the object is, theoretically, inactive after valuing its Case feature. Finally, in (48), the dative object moves before the subject in order to receive interpretation as discourse-given ${ }^{39}$. If all Case features on the above objects are $[u, u \mathrm{val}]$, being then valued and deleted at the level of the $v \mathrm{P}$ phase, it is not at all clear how the oblique initial DPs in (45-48) contribute to semantic interpretation. Moreover, if it is the $[u u \mathrm{val}]$ feature on the Goal that makes it visible by the

39 As regards (45), Nevins (2004: 294) notes that the accusative soldat ('soldiers') occupies an A-position owing to the fact that it does not induce weak crossover. As regards Polish (46), it is argued that TP is absent (Tajsner 1998), which would mean that the oblique DP is probably hosted in TopP. 
Probe, it is unclear how the very feature valuation operation can be initiated ${ }^{40}$. These problems disappear if Case and gender remain [i], because LIs can still participate in further operations - provided that they are attracted by the Edge Feature of the $v \mathrm{P}$ phase. As regards legitimate feature valuation, nothing bans the Goal from having $[i \mathrm{val}]$ features in order to be probed - what matters is that the Probe's feature is [ $u \mathrm{val}]$ because such features have to be disposed with before they connect with the interfaces. In the case at hand, the feature valuation between Top $^{0}$ (Probe) and demonstrative/DP (Goal) involves the following features: $[i u \mathrm{val}+\mathrm{ref}]$ on the former, and $[i \mathrm{val}+\mathrm{ref}]$ on the latter, which is a configuration that yields an appropriate Agree relation (cf. Bošković 2011: 9).

Before we close this issue, however, an important question has to be asked. If Case and gender features are [i] on nouns and demonstratives do they not violate FI? The relevant features seem to be interpreted twice, but the noun clearly cannot be feminine or accusative twice. As regards FI, it could be proposed that nothing is violated because the features are per se legitimate objects when they reach FI. To the best of our knowledge, FI requires that all features receive interpretation at the interfaces, which is what happens here as well (see Inokuma 2013 on multiple feature interpretation within DPs). Notably, we have already argued that Case and gender map onto features that are semantically part of the nominal category, and that they provide a value for another feature, i.e., definiteness when present on the functional category of a demonstrative (cf. Josefsson 2013; Citko 2014: 17). We could, therefore, propose that the fact that Case and gender are $[i]$ on the noun and on the demonstrative, does not hinder FI - the two instances of these features receive different interpretation at the interfaces. In other words, on the nominal level, Case and gender function as a classificatory device of a noun, which provides information on what type of anaphoric relation, for example, the noun will show (e.g., correlation with masculine or neuter pronoun). That would, perhaps, reflect what Millar had in mind in saying that "grammatical gender acts largely as a means of keeping the nominal system's 'house in order' (Millar 2000: 34). The same features on the determiner level would, however, be mapped onto the definiteness feature allowing the nominal to participate in derivational steps that allow it to be part (or not) of the proposition at the level of TP or discoursedeictic representation established in TopP, for example ${ }^{41}$.

40 If the Goal's features are $[u, u \mathrm{val}]$, the Probe will be unable to initiate Agree neither when it has the $[u]$ feature nor when it has the $[i]$ feature. In the former case, the Probe is unable to value the $[u]$ feature of the Goal, and in the latter, the probing operation cannot be initiated because the Probe has no $[u]$ features to value (cf. Bošković 2011).

41 This could be conflated with Hockett's idea that "genders are classes of nouns reflected in the behaviour of associated words" (Hockett 1958: 231). In a more detail-oriented perspective, demonstratives, determiners, or demonstrative pronouns, when dominating the nominal 
Let us, finally, consider the distinction between demonstratives and personal pronouns. Howe (1996), for example, shows that the former have stronger reference than the latter, which is also the viewpoint advocated by van Gelderen (2011a: 8). Specifically, both categories can be anaphors, although demonstratives can also act as relative pronouns (cf. Wiltschko 1998) ${ }^{42}$. Interestingly, for van Gelderen $(2011 \mathrm{a}, 2011 \mathrm{~b})$ the $[i] 3^{\text {rd }}$ person feature accounts for the pronominal property of demonstratives, and the [i-loc] deictic features absent in pronouns explain the difference between the two categories. However, in Table 1 we can distinguish contrasts in gender, Case, and number, but not person. The distinction into person comes out only when demonstratives are perceived as variants of personal pronouns ${ }^{43}$. In, and of themselves, the former are unspecified for person in the same way they are unspecified for gender in $[-\mathrm{Sg}]$ contexts. As for personal pronouns, they differ, because, although it is only $3^{\text {rd }}$ person forms that act as anaphors, the entire pronominal paradigm includes also $1^{\text {st }}$ and $2^{\text {nd }}$ person forms, and yields morphological contrasts that allow for the postulation of the person feature. It is doubtful that the $[i]$ person feature would suffice to yield specific reference - the above examination shows that the richer the morphology is, the easier it is to produce deictic and syntactic linking between two DPs. The correlation between the Case form and reference type it induces, i.e., [nominative $>$ topic continuation] vs. [oblique $>$ topic shift], is of that kind and neither of the two correlations requires the presence of the person feature. What is more, in van Gelderen's (2011a, 2011b) approach, it is not obvious why personal pronouns cannot shift topics and display deictic properties despite carrying an even richer array of formal features, i.e., the additional person feature ${ }^{44}$.

We remain agnostic as to whether it is the status of the person feature that makes the difference between distribution and properties of demonstratives and personal pronouns in OE. Quite possibly though, it may be the case that the relevant features, i.e., person, gender, and Case, if present, map onto different categories like

category, yield maximally specific reference, i.e., reference to specific individuals as defined in Sheehan \& Hinzen (2011: 3-4).

42 See also Bellmann (1990) and van Gelderen (2014).

43 Interestingly, both demonstratives and pronouns show near one-to-one correlation in gender and Case morphology. Thus, there is no qualitative difference between the two to postulate the deictic features for the former, and not for the latter. The OE personal pronouns are as follows (masc/fem/neut, respectively) (Malak 2008: 110): hê/hēo/hit in [nom, Sg], his/hire/his in [gen, $\mathrm{Sg}$ ], him/hire/him in [dat, Sg] and hine/hie/hit in [acc, Sg]. The plural forms decline only for Case as se demonstratives: hie/hira/him/hie.

44 The distribution and properties of demonstrative and personal pronouns may indicate that some other issues play a role here. As shown in van Gelderen (2011a, 2011b), demonstrative pronouns sometimes do not shift topics and personal pronouns sometimes act as deictic markers. We leave this issue for space reasons here. 
definiteness on a functional category of demonstratives/determiners, unlike on nouns and pronouns where they "map into semantically relevant features" (Citko 2014: 17). That would account for the fact that the definite, referentially-specific property of demonstratives holds even though they are used 'pronominally"45.

\section{Concluding remarks}

This paper has argued that the loss of grammatical Case and gender features has serious consequences for the syntactic and pragmatic properties of the $\mathrm{OE}$ simple demonstratives, which is especially visible in the demise of the topic shift option. It has been assumed, for the sake of the discussion, that inflectional morphology constitutes a fully-fledged component of syntax. This allowed us to argue that the levelling of inflectional endings on simple demonstratives that took place between $\mathrm{OE}$ and EME has been the primary factor leading to the changes in question. The above viewpoint seems justified considering the fact that simple demonstratives are unable to function independently in the sentence when the loss of morphology is complete.

Adopting such a viewpoint required that the examination be based on the SMT hypothesis (Chomsky 2001) whereby language, as a manifestation of the Language Faculty, is the optimal solution to satisfy requirements of systems external to language. Several examples from Polish and Icelandic involving the so-called quirky subject constructions have been discussed, with the aim of showing that morpho-phonological agreement affects not only semantic, but also syntactic properties of nominals. On the basis of these findings, as well as semantic and distributional properties of the OE simple demonstratives, we have assumed that their Case and gender features contribute to semantic interpretation: they are interpretable and visible at the interfaces. Considering that topicalisation of nominals involves mainly those dominated by either the D-category or the D-category itself (if we disregard proper names), it has been proposed that the latter category provides the nominal complement with specific reference that allows for unambiguous discourse-linking.

In order to account for the syntax-semantic heterogeneity of the OE simple demonstratives, we have adopted Pesetsky \& Torrego's (2007) feature valuation

45 Another possibility would be to distinguish demonstratives from personal pronouns structurally as in Tappe (1990) or Wiltschko (1998). The initial bound morpheme or morpheme cluster $-s / b(V)$ in the former as an instantiation of a $+\mathrm{D}$ category with a $[+$ ref $/ \mathrm{spec}]$ property would be located in $\left[\mathrm{D}^{0}\right]$, while personal pronoun forms without such morpheme would be confined to some lower functional projection in DP where they would be instantiations of person agreement lacking the $-s / p(V)$ and, consequently, the $[+\mathrm{ref} / \mathrm{spec}]$ property. Such an option also seems to fit into the approach offered here. See Wiltschko (1998) for a similar treatment of this issue in German. 
perspective whereby feature occurrences combine into two instantiations of one formal object. Crucially, the assumption that the Agree relation applies regardless of the feature's interpretability helped us to maintain the interpretable Case and gender features on the OE demonstratives, with the proviso that gender is [ $i \mathrm{val}]$ when the demonstrative occurs independently, and [i $u \mathrm{val}]$ when it is followed by the nominal complement - the [uval] status reflecting the fact that the demonstrative values gender while agreeing with the noun.

The feature specification of the OE demonstratives, as proposed above, has become crucial when examining their distributional and discourse properties in the sentence. We have focussed on pre-TP contexts featuring topicalised objects including pronominal instances of simple demonstratives. Adopting Rizzi's (1997) representation of the Left Periphery of the sentence, it has been argued that the $\mathrm{OE}$ demonstratives move to $\left[\mathrm{Spec}, \mathrm{TopP}^{0}\right]$ where they value $\mathrm{Top}^{0}$ 's [i $u \mathrm{val}+\mathrm{ref} / \mathrm{spec}]$ feature. It is this syntactic position in which demonstratives become interpreted as discourse-old owing to the already mentioned Case and gender features. That the above viewpoint is on the right track seems to be supported from the data coming from German and Dutch. The D-systems in the two languages feature grammatical Case and gender on the one hand, and display similar deictic properties, on the other. In particular, they refer to nontopical antecedents in the previous clause.

The detailed examination of the OE topic shift constructions whereby the object of the previous sentence becomes the topic of the next sentence has shown a complex relation between the Case form and the grammatical gender the two nominals show in the anaphoric relation. While the use of different Case forms specifies the structural position of the nominal and its semantic interpretation as an object or subject, the use of a particular gender form establishes specific anaphoric reference in which the two nominals are interpreted as two instances of the same entity mentioned in the discourse. In the case at hand, the masculine gender on pam links it to the masculine anaphor wingeard in the previous sentence.

This highly articulate paradigm has been shown to fall apart in EME due to the inflectional levelling of the D-system. The emergence of the morphologically invariant form $p e$ involves serious morphological, syntactic and discourse-pragmatic effects. In essence, the loss of grammatical Case and gender makes it unable to posit any feature, and hence, inherent morphological contrast on the EME $p e$, which marks the point of shifting the Case and the gender feature to the semantic pole. In more formal terms, the feature-valuation between $\mathrm{D}^{0}$ and $p e$ can no longer hold via movement, ultimately leading to the external merge of $p e$ in $\mathrm{D}^{0}$ and its structural reanalysis into a definite article. Because $p e$ now carries $u \varphi$-features, it can only value $\mathrm{D}^{0}$ 's [uref] feature - the $i \varphi$-features have to be provided by the nominal complement which now 
obligatorily follows the definite article. This is shown by EME examples like (32), where her shadow in the previous clause becomes referred to by the anaphoric pe shadewe, i.e., the definite article that has to pied-pipe the nominal complement. This is dictated by FI, i.e., the requirement that each LI becomes PF- and LF-interpretable at the interfaces. It follows then that the lack of $[i]$ Case and gender features disallows be to identify TopP independently. Crucially, as has also been shown, topic shift property is partly taken over by the newly emerged this/that demonstratives which can surface independently owing to the [ \pm proximal] opposition manifested morpho-phonologically.

Finally, the approach adopted in the present paper has been shown to provide a more theoretically-valid account for the properties and distribution of personal and demonstrative pronouns than that of van Gelderen (2011a, 2011b). It has been proposed that it is the lack of the person feature in the latter category and its presence in the former that makes the difference between the two categories. The lack of the person feature on the $\mathrm{OE}$ demonstratives considerably reduces their pronominal property, i.e., they fail to refer to topical antecedents like personal pronouns. On the other hand, the lack of the person feature accounts for their deictic-referencing and independent anaphoric use - the two being secured by overt Case and gender $[i]$ features.

\section{PRIMARY SOURCES}

Hall, Joseph. 1920. Selections from Early Middle English, 1130-1250, 2 vols. Oxford: Clarendon Press.

Morris, Richard (ed.). 1868-1873. Old English homilies and homiletic treatises. EETS OS 29, 34, 53. London: Trübner.

Plummer, Charles \& John Earle (eds). 1892-1889. Two of the Saxon chronicles parallel. 2 vols. Oxford: Clarendon Press.

Sweet, Henry (ed.). 1871. King Alfred's West-Saxon version of Gregory's Pastoral Care. EETS OS 45, 50. London: Oxford University Press.

Thorpe, Benjamin (ed.). 1844. The homilies of the Anglo-Saxon church: The first part containing the Sermones Catholici, or homilies of Elfric. 2 vols. London: Ælfric Society.

\section{REFERENCES}

Abraham, Werner. 2007. Discourse binding: DP and pronouns in German, Dutch, and English. In Elisabeth Stark, Elisabeth Leiss \& Werner Abraham (eds.), Nominal determination: Typology, context constraints, and historical emergence, 21-48. Amsterdam: John Benjamins. DOI: 10.1075/slcs.89.04abr

Adger, David. 2003. Core syntax: A minimalist approach. Oxford: Oxford University Press. 
Adger, David \& Peter Svenonius. 2009. Features in Minimalist syntax. https://ling.auf.net/lingbuzz/000825 (accessed on 19 December, 2015)

Alexiadou, Artemis, Liliane Haegeman \& Melita Stavrou. 2007. Noun phrase in the generative perspective. Berlin: Mouton de Gruyter.

Allen, Cynthia L. 1995. Case marking and reanalysis: Grammatical relations from Old to Early Modern English. Oxford: Clarendon Press.

Allen, Cynthia L. 2006. Possessives and determiners in Old English. In Terttu Nevalainen, Juhani Klemola \& Mikko Laitinen (eds.), Types of variation: Diachronic, dialectal and typological interfaces, 149-170. Amsterdam \& Philadelphia, PA: John Benjamins. DOI: $10.1075 /$ slcs.76.09all

Allen, Cynthia L. 2012. Why a determiner? The Possessive + Determiner + Adjective construction in Old English. In Anneli Meurman-Solin, Maria José López-Couso \& Bettelou Los (eds.), Information structure and syntactic change in the history of English, 245-270. Oxford: Oxford University Press. DOI: 10.1093/acprof:oso/9780199860210.003.0011

Baker, Mark C. 2008. The syntax of agreement and concord. Cambridge: Cambridge University Press.

Barðdal, Jóhanna. 2001. The perplexity of Dat-Nom verbs in Icelandic. Nordic Journal of Linguistics 24(1). 47-70. DOI: 10.1080/03325860117730

Bartnik, Artur. 2007. Categorial heterogenity: Old English determiners. Studia Anglica Posnaniensia 43. 75-96.

Bartnik, Artur. 2011. Noun Phrase structure in Old English. Quantifiers and other functional categories. Lublin: Wydawnictwo KUL.

Bech, Kristin. 2012. Word order, information structure, and discourse relations: A study of Old and Middle English verb-final clauses. In Anneli Meurman-Solin, Maria José LópezCouso \& Bettelou Los (eds.), Information structure and syntactic change in the history of English, 65-86. Oxford: Oxford University Press. DOI: 10.1093/acprof:oso/9780199860210.003.0004

Bech, Kristin \& Christine M. Salvesen. 2014. Preverbal word order in Old English and Old French. In Kristin Bech \& Kristine G. Eide (eds.), Information structure and syntactic change in Germanic and Romance languages, 233-270. Amsterdam \& Philadelphia, PA: John Benjamins. DOI: 10.1075/la.213.09bec

Beghelli, Filippo \& Tim Stowell. 1994. The direction of quantifier movement. GLOW Newsletter 32. 56-57.

Bellmann, Günter. 1990. Pronomen und Korrektur. Zur Pragmalinguistik der persönlichen Referenzformen. Berlin \& New York: de Gruyter.

Biberauer, Theresa \& Ian Roberts. 2010. Subjects, Tense, and verb-agreement. In Theresa Biberauer, Anders Holmberg, Ian Roberts \& Michelle Sheehan (eds.), Parametric variation: Null subjects in minimalist theory, 263-302. Cambridge: Cambridge University Press.

Biberauer, Theresa, Anders Holmberg, Ian Roberts \& Michelle Sheehan (eds.). 2010. Parametric variation: Null subjects in Minimalist theory. Cambridge: Cambridge University Press.

Billet, Jesse D. 2014. The divine office in Anglo-Saxon England, 597-c.1000. London: Henry Bradshaw Society.

Blake, Barry, J. 1994. Case. Cambridge: Cambridge University Press. 
Boeckx, Cedric. 2000. Quirky agreement. Studia Linguistica 54(3). 354-380. DOI: 10.1111/14679582.00070

Bohnacker, Ute \& Christina Rosén. 2007. How to start a V2 declarative clause: Transfer of syntax vs. information structure in L2 German. Nordlyd 34(3). 29-56. DOI: 10.7557/12.122

Bondaruk, Anna \& Bogdan Szymanek. 2007. Polish nominativeless constructions with dative Experiencers: Form, meaning and structure. Studies in Polish Linguistics 4. 61-97.

Bošković, Željko. 2011. On unvalued uninterpretable features. In Suzi Lima, Kevin Mullin \& Brian Smith (eds.), Proceedings of the 39th Annual Meeting of the North Eastern Linguistics Society. 109-120. Amherst: Department of Linguistics.

Breban, Tine. 2012. Functional shifts and the development of English determiners. In Anneli Meurman-Solin, Maria José Lpez-Couso \& Bettelou Los (eds.), Information structure and syntactic change in the history of English, 271-300. Oxford: Oxford University Press. DOI: 10.1093/acprof:oso/9780199860210.003.0012

Brugè, Laura. 2002. The positions of demonstratives in the extended nominal projection. In Guglielmo Cinque (ed.), Functional structure in DP and IP. The cartography of syntactic structures, 15-53. Oxford: Oxford University Press.

Brunner, Karl. 1963. An outline of Middle English grammar (translated by Grahame Johnson). Oxford: Blackwell.

Carstens, Vicki. 1993. Deriving agreement. Invited talk. Dept. of Linguistics and Philosophy, MIT.

Carstens, Vicki. 2010. Implications of grammatical gender for the theory of uninterpretable features. In Michael Putnam (ed.), Exploring crash-proof grammars, 31-57. Amsterdam: John Benjamins.

Chomsky, Noam. 1981. Lectures on government and binding: The Pisa lectures. Dordrecht: Foris.

Chomsky, Noam. 1986. Knowledge of language: Its nature, origin, and use. New York, NY: Praeger.

Chomsky, Noam. 1995. The Minimalist program. Cambridge, MA: The MIT Press.

Chomsky, Noam. 2001. Derivation by phase. In Michael Kenstowicz (ed.), Ken Hale: A life in language, 1-52. Cambridge, MA: MIT Press.

Chomsky, Noam. 2004. Beyond explanatory adequacy. In Adriana Belletti (ed.), Structures and beyond: The cartography of syntactic structures, 104-131. Oxford: Oxford University Press.

Chomsky, Noam. 2008. On phases. In Robert Freidin, Carlos P. Otero \& Maria Luisa Zubizarreta (eds.), Foundational issues in linguistic theory. Essays in honour of Jean-Roger Vergnaud, 134-166. Cambridge, MA: The MIT Press. DOI: 10.7551/mitpress/9780262062787.003.0007

Citko, Barbara. 2014. Phase theory. An introduction. Cambridge: Cambridge University Press.

Crisma, Paola. 2011. The emergence of the definite article in English. A contact-induced change? In Petra Sleeman \& Harry Perridon (eds.), The Noun Phrase in Romance and Germanic: Structure, variation, and change, 175-192. Amsterdam \& Philadelphia, PA: John Benjamins. DOI: 10.1075/1a.171.13cri

Danon, Gabi. 2011. Agreement and DP-internal feature distribution. Syntax 14(4). 297-317. DOI: 10.1111/j.1467-9612.2011.00154.x

Diamond, Robert E. 1970. Old English grammar \& reader. Detroit: Wayne State University Press. 
Diessel, Holger. 1999. Demonstratives: Form, function and grammaticalization. Amsterdam: John Benjamins. DOI: 10.1075/tsl.42

Domenico, Elisa di. 1997. Per una teoria del genere grammatical. Padova: Unipress.

Eitler, Tamás \& Marit Westergaard. 2014. Word order variation in late Middle English: The effect of information structure and audience design. In Kristin Bech \& Kristine G. Eide (eds.), Information structure and syntactic change in Germanic and Romance languages, 203-232. Amsterdam \& Philadelphia, PA: John Benjamins. DOI: 10.1075/la.213.08eit

Embick, David \& Rolf Noyer. 2001. Movement operations after syntax. Linguistic Inquiry 32(4). 555-595. DOI: 10.1162/002438901753373005

Farkas, Donka F. \& Henriëtte de Swart. 2007. Article choice in plural generics. Lingua 117(9). 1657-1676. DOI: 10.1016/j.lingua.2006.06.011

Farkas, Donka F. \& Klaus von Heusinger. 2003. Stability of reference and object marking in Romanian. Paper presented at Workshop on direct Reference and Specificity (ESSLI), Vienna, August 2003.

Fischer, Olga, Ans van Kemenade, Willem Koopman \& Wim van der Wurff. 2000. The syntax of Early English. Cambridge: Cambridge University Press. DOI: 10.1017/CBO9780511612312

Fisiak, Jacek. 1968. A short grammar of Middle English. Warszawa: Wydawnictwo Naukowe PWN.

Fulk, Richard D. 2012. An introduction to Middle English: Grammar and texts. Peterborough, ON: Broadview Press.

Gelderen, Elly van. 2011a. The diachrony of pronouns and demonstratives. http://www.public.asu.edu/ gelderen/JT-FS-August-2011.pdf (accessed on 11 January 2016).

Gelderen, Elly van. 2011b. The linguistic cycle: Language change and the language faculty. New York, NY: Oxford University Press. DOI: 10.1093/acprof:oso/9780199756056.001.0001

Gelderen, Elly van. 2014. Semantic and formal features: Feature economy in language change. In Chiara Gianollo, Agnes Jäger \& Doris Penka (eds.), Language change at the syntaxsemantics interface, 33-56. Berlin \& Munich: Mouton de Gruyter. DOI: $10.1515 / 9783110352306.33$

Gerritsen, Marinel. 2002. Towards a more gender-fair usage in Netherlands Dutch. In Marlis Hellinger \& Hadumod Bußmann (eds.), Gender across languages: The linguistic representation of women and men, vol. 2, 81-108. Amsterdam \& Philadelphia, PA: John Benjamins. DOI: 10.1075/impact.10.10ger

Giusti, Giuliana. 2001. The birth of a functional category: From Latin ille to the Romance article and personal pronoun. In Guglielmo Cinque \& Giampaolo Salvi (eds.), 157-171. Current studies in Italian syntax: Essays offered to Lorenzo Renzi. Amsterdam: North Holland.

Hale, Kenneth \& Maria Bittner. 1996. The structural determination of case and agreement. Linguistic Inquiry 27. 1-68.

Halle, Morris \& Alec Marantz. 1993. Distributed morphology and the pieces of inflection. In Kenneth Hale \& Samuel Jay Keyser (eds.), The view from building 20. 111-176. Cambridge, MA: The MIT Press.

Harley, Heidi \& Rolf Noyer. 1999. Distributed morphology. Glot International 4(4). 3-9. 
Hinterwimmer, Stefan. 2014. A unified account of the properties of demonstrative pronouns in German.https://docs.google.com/viewer?a=v\&pid=sites\&srcid=ZGVmYXVsdGRvb WFpbnxzdGVmYW5oaW50ZXJ3aW1tZXJ8Z3g6N2EzMTJjNWExYWV1YmEwO $\mathrm{Q}$ (accessed on 12 March 2016).

Hockett, Charles F. 1958. A course in modern linguistics. New York, NY: Macmillan.

Hogg, Richard M. 2002. An introduction to Old English. Edinburgh: Edinburgh University Press.

Hogg, Richard M. \& Robert D. Fulk. 2011. A grammar of Old English: Morphology. Chichester: Wiley Blackwell.

Howe, Stephen. 1996. The personal pronouns in the Germanic languages: A study of personal pronoun morphology and change in the Germanic languages from the first records to the present day. Berlin: Walter de Gruyter.

Inokuma, Sakumi. 2013. Distribution of phi-features within DPs and the activity condition. English Linguistics 30(1). 292-312. DOI: 10.9793/elsj.30.1_292

Jónsson, Jóhannes Gísli. 2003. Not so quirky: On subject case in Icelandic. In Ellen Brandner \& Heike Zinsmeister (eds.), New perspectives in case theory, 127-164. Stanford: CSLI Publications.

Josefsson, Gunlög. 2013. Gender in Scandinavian: On the gender systems in Mainland Scandinavian, with focus on Swedish. http://ling.auf.net/lingbuzz/001966 (accessed on 21 December 2015)

Jurczyk, Rafał. 2015. The logical-semantic content of subject: A configurational view from syntax and LF. Poznań Studies in Contemporary Linguistics 51(1). 89-131. DOI: 10.1515/psicl-2015-0004

Kemenade, Ans van \& Marit Westergaard. 2012. Syntax and information structure: Verb-second variation in Middle English. In Anneli Meurman-Solin, Maria José López-Couso \& Bettelou Los (eds.), Information structure and syntactic change in the history of English, 87-118. Oxford: Oxford University Press. DOI: 10.1093/acprof:oso/9780199860210.003.0005

Kibrik, Andrej A. 2011. Reference in discourse. Oxford: Oxford University Press. $\quad$ DOI: 10.1093/acprof:oso/9780199215805.001.0001

Kiss, Katalin É. 2002. The EPP in a topic-prominent language. In Peter Svenonius (ed.), Subjects, expletives, and the EPP, 107-124. Oxford: Oxford University Press.

Klijs, Gerard P. C. 2013. The use of demonstratives in Dutch telephone conversations: Comparing the traditional view on demonstratives with recent insights. Utrecht: University of Utrecht M.A. Thesis. https://dspace.library.uu.n1/handle/1874/276688

Koeneman, Olaf. 2000. The flexible nature of verb movement. Utrecht: University of Utrecht Ph.D. Dissertation. https://www.lotpublications.nl/the-flexible-nature-of-verbmovement-the-flexible-nature-of-verb-movement

Kroch, Anthony \& Ann Taylor. 1997. Verb movement in Old and Middle English: Dialect variation and language contact. In Ans van Kemenade \& Nigel Vincent (eds.), Parameters of morphosyntactic change, 297-325. Cambridge: Cambridge University Press.

Kuno, Masakazu. 2011. Separating feature interpretability from feature values: Evidence from negative concord in Japanese. Generative Grammar in Geneva 7. 23-32.

Laing, Margaret. 1993. Catalogue of sources for a linguistic atlas of Early Medieval English. Cambridge: D.S. Brewer.

Lavine, James E. \& Robert Freidin. 2002. The subject of defective T(ense) in Slavic. Journal of Slavic Linguistics 10(1-2). 251-287. 
Longobardi, Giuseppe. 1994. Reference and proper names: A theory of N-movement in syntax and logical form. Linguistic Inquiry 25(4). 609-665.

Los, Bettelou. 2012. The loss of verb-second and the switch from bounded to unbounded systems. In Anneli Meurman-Solin, Maria José López-Couso \& Bettelou Los (eds.), Information structure and syntactic change in the history of English, 21-46. Oxford: Oxford University Press. DOI: 10.1093/acprof:oso/9780199860210.003.0002

Lyons, Christopher. 1999. Definiteness. Cambridge: Cambridge University Press. DOI: 10.1017/CBO9780511605789

Malak, Janusz. 2008. Derivational conspiracy: The demise of subjectless clauses in English. Opole: Uniwersytet Opolski.

Markus, Manfred. 1995. On the growing role of semantic and pragmatic features in Middle English. In Jacek Fisiak (ed.), Linguistic change under contact conditions, 161-178. Berlin: Mouton. DOI: 10.1515/9783110885170.161

Millar, Robert McColl. 2000. System collapse - system rebirth: The demonstrative pronouns of English 900-1350 and the rise of the definite article. Bern: Peter Lang AG.

Moro, Andrea. 2008. The boundaries of Babel: The brain and the enigma of impossible languages. Cambridge, MA: The MIT Press. DOI: 10.7551/mitpress/97

Neeleman, Ad \& Fred Weerman. 2001. Flexible syntax: A theory of case and arguments. Dordrecht: Kluwer Academic Publisher.

Nevins, Andrew. 2004. Derivations without the Activity Condition. MIT Working Papers in Linguistics 49. 287-310.

Nossalik, Larissa. 2005. The A/A'-status of Russian scrambling. McGill Working Papers in Linguistics 19(2). 65-102.

Osawa, Fuyo. 2007. The emergence of DP from a perspective of ontogeny and phylogeny: Correlation between DP, TP and aspect in Old English and first language acquisition. In Elisabeth Stark, Elisabeth Leiss \& Werner Abraham (eds.), Nominal determination: Typology, context constraints, and historical emergence, 311-337. Amsterdam: John Benjamins. DOI: 10.1075/slcs.89.17osa

Pesetsky, David \& Esther Torrego. 2007. The syntax of valuation and the interpretability of features. In Simin Karimi, Vida Samiian \& Wendy K. Wilkins (eds.), Phrasal and clausal architecture: Syntactic derivation and interpretation, In honor of Joseph E. Emonds, 262-294. Amsterdam: John Benjamins. DOI: 10.1075/la.101.14pes

Picallo, M. 2008. Gender and number in Romance. Lingue e Linguaggio 7(1). 47-66.

Pinker, Steven. 1994. The language instinct. New York, NY: Harper Perennial Modern Classics.

Radford, Andrew. 2004. Minimalist syntax. Exploring the structure of English. Cambridge: Cambridge University Press. DOI: 10.1017/CBO9780511811319

Ralli, Angela. 2003. Morphology in Greek linguistics: The state of the art. Journal of Greek Linguistics 4(1). 77-129. DOI: 10.1075/jgl.4.09ral

Ritter, Elisabeth. 1991. Two functional categories in noun phrases: Evidence from Modern Hebrew. In Susan Rothstein (ed.), Syntax and semantics, vol. 25. Perspectives on phrase structure: Heads and licensing. 37-62. London: Academic Press.

Ritter, Elisabeth. 1993. Where's gender? Linguistic Inquiry 24(3). 795-803.

Rizzi, Luigi. 1997. The fine structure of the left periphery. In Liliane Haegeman (ed.), Elements of grammar: Handbook in generative syntax. 281-337. Dordrecht: Kluwer.

Roberts Ian \& Anna Roussou. 2002. The Extended Projection Principle as a condition on the tense dependency. In Peter Svenonius (ed.), Subjects, expletives, and the EPP, 125 156. Oxford: Oxford University Press. 
Rohrbacher, Bernard. 1994. Notes on the antisymmetry of syntax. University of Pennsylvania Working Papers in Linguistics 1(1). 111-128. http://repository.upenn.edu/pwpl/vol1/iss1/8/

Salverda, Reinier. 1982. On the problem of topicalization in Dutch. Voortgang 3. 244-256.

Sheehan, Michelle \& Wolfram Hinzen. 2011. Moving towards the edge. Linguistic Analysis 37. 405-458.

Sigurðsson, Halldór Ármann. 1996. Icelandic finite verb agreement. Working Papers in Scandinavian Syntax 57. 1-46.

Stutterheim, Christiane von \& Mary Carroll. 2005. Subjektwahl und Topikkontinuität im Deutschen und Englischen. Zeitschrift für Literaturwissenschaft und Linguistik 35(3). 7-27. DOI: 10.1007/BF03379441

Svenonius, Peter (ed.). 2002. Subjects, expletives, and the EPP. Oxford: Oxford University Press.

Tajsner, Przemysław. 1998. XP-fronting in Polish. Papers and Studies in Contemporary Linguistics 34. 75-99.

Tajsner, Przemysław. 2012. Minimalizm z perspektywy biolingwistyki. In Piotr Stalmaszczyk (ed.), Studia z metodologii i filozofii językoznawstwa: Wspótczesne językoznawstwo generatywne. Podstawy metodologiczne, 87-116. Łódź: Primum Verbum.

Tappe, Hans Thilo. 1990. Determiner phrases and agreement in German. Unpublished manuscript: University of Göttingen.

Taylor, Ann \& Susan Pintzuk. 2014. Testing the theory: Information structure in Old English. In Kristin Bech \& Kristine G. Eide (eds.), Information structure and syntactic change in Germanic and Romance languages, 53-78. Amsterdam \& Philadelphia, PA: John Benjamins. DOI: 10.1075/la.213.03tay

Toman, Jindrich. 1994. Case as a functional projection: A note on an issue in parametrization. In Jindrich Toman (ed.), Annual Workshop on Formal Approaches to Slavic Linguistics: The Ann Arbor meeting. Functional categories in Slavic syntax, 173-181. Ann Arbor, MI: Michigan Slavic Publications.

Trips, Carola. 2002. From OV to VO in Early Middle English. Amsterdam: John Benjamins. DOI: 10.1075/la.60

Ura, Hiroyuki. 2000. Checking theory and grammatical functions in universal grammar. Oxford: Oxford University Press.

Valois, Daniel. 1991. The internal syntax of DP. Los Angeles, CA: University of California Ph.D. dissertation.

Vangsnes, Øystein A. 2002. Icelandic expletive constructions and the distribution of subject types. In Peter Svenonius (ed.), Subjects, expletives, and the EPP, 43-70. Oxford: Oxford University Press.

Watanabe, Akira. 2009. A parametric shift in the D-system in Early Middle English: Relativization, articles, adjectival inflection, and indeterminates. In Paola Crisma \& Giuseppe Longobardi (eds.), Historical syntax and linguistic theory, 358-374. Oxford: Oxford University Press. DOI: 10.1093/acprof:oso/9780199560547.003.0021

Wyatt, Alfred J. 1897. An elementary Old English reader (early West Saxon). Cambridge: Cambridge University Press.

Willim, Ewa. 2012. O przyczynach zmian głównych kierunków badawczych w gramatyce generatywnej Noama Chomsky'ego (1957-2007) . In Piotr Stalmaszczyk (ed.), Studia z metodologii i filozofii językoznawstwa: Wspótczesne językoznawstwo generatywne. Podstawy metodologiczne, 18-86. Łódź: Primum Verbum. 
Wiltschko, Martina. 1998. On the syntax and semantics of (relative) pronouns and determiners. Journal of Comparative Germanic Linguistics 2(2). 143-181. DOI: 10.1023/A:1009719229992

Wood, Johanna L. 2007. Demonstratives and possessives: From Old English to present-day English. In Elisabeth Stark, Elisabeth Leiss \& Werner Abraham (eds.), Nominal determination: Typology, context constraints, and historical emergence, 339-361. Amsterdam: John Benjamins. DOI: 10.1075/slcs.89.18woo 